\title{
Chemical characteristics of particulate organic matter from a small, mountainous river system in the Oregon Coast Range, USA
}

\author{
Jeff A. Hatten • Miguel A. Goñi • \\ Robert A. Wheatcroft
}

Received: 19 March 2010/ Accepted: 16 September 2010/Published online: 15 October 2010

(C) The Author(s) 2010. This article is published with open access at Springerlink.com

\begin{abstract}
To better understand the transfer of particulate organic matter (POM) by small mountainous river systems (SMRS) to the ocean, we measured the concentration and composition of suspended particles from the Alsea River, a SMRS in the Oregon Coast Range, over a wide range of discharges that included several floods. All particulate constituents measured, including organic carbon, nitrogen and biomarkers such as lignin-derived phenols, cutin acids and amino acid-derived products, displayed concentrations that increased as a power function of discharge. In contrast to other SMRS, virtually all POM in the Alsea River samples was modern and had an average age $<60$ year. In spite of their similar ${ }^{14} \mathrm{C}$ ages, marked contrasts in elemental and biomarker compositions were evident in particles collected at low and high discharges. Particles at low flows were primarily composed of organic detritus from non-vegetation sources (e.g., algal cells) whereas mineral-rich particles containing vegetation and soil-derived POM were predominant at elevated flows. Biomarker compositions of these latter particles suggest most of the POM
\end{abstract}

\footnotetext{
J. A. Hatten

Department of Forestry, Mississippi State University, Mississippi State, MS 39762, USA
}

M. A. Goñi $(\varangle) \cdot$ R. A. Wheatcroft

College of Oceanic and Atmospheric Sciences,

Oregon State University, 104 Ocean Admin. Bldg,

Corvallis, OR 97331, USA

e-mail:mGoni@coas.oregonstate.edu originated from areas if the watershed with measurable hardwood contributions, which include areas affected by shallow landslides and riparian zones. We infer that the low uplift rates, lush vegetation, high net primary production and relatively thick soils that characterize the Alsea watershed are responsible for these trends. Comparison of our results with those from other systems, including the well-studied Santa Clara River (southern California), demonstrates that SMRS are part of a continuum whereby contrasts in hydroclimate, geology and vegetation lead to significant differences in the age and composition of POM exported to the ocean.

Keywords Carbon - Small mountainous rivers . Particulate organic carbon - River discharge . Stable isotopes · Radiocarbon · Organic biomarkers

\section{Introduction}

Small, mountainous river systems (SMRS) deliver over half of the global sediment supply to the world's oceans (Milliman and Syvitski 1992) and may account for a similar fraction of the global particulate organic matter (POM) flux (Lyons et al. 2002; Gomez et al. 2003; Coynel et al. 2005). The importance of SMRS has motivated an increasing number of studies focused on determining the characteristics of these systems, which contrast markedly from the fifty or so 
largest rivers of the world. To date, the majority of SMRS studies have focused on rivers with elevated sediment yields such as the Santa Clara and Eel rivers (California, USA), Waipoa River (New Zealand) and Lanyang Hsi and LiWu Rivers (Taiwan) (e.g., Masiello and Druffel 2001; Komada et al. 2004, 2005; Gomez et al. 2003; Blair et al. 2003; Leithold et al. 2006; Kao and Liu 1996; Hilton et al. 2008a, b). The conceptual picture emerging from these studies is that the majority of the POM delivered by SMRS is ancient (i.e., depleted in ${ }^{14} \mathrm{C}$ ) and derived from geologic sources such as deep soils and/or bedrock. The rest of the POM is thought to be made up of the remains of living organisms with relatively short residence times (i.e., enriched in ${ }^{14} \mathrm{C}$ ) within the watershed (e.g., Blair et al. 2004). For consistency, in this paper, we use the term petrogenic to describe ${ }^{14} \mathrm{C}$-free (i.e. fossil) POM associated with sedimentary rocks that has undergone extensive diagenesis over geologic time scales. In contrast, we use the term biogenic to describe POM (including vegetation and soil organic matter) derived from living organisms but which may have distinct residence times, and hence variable ${ }^{14} \mathrm{C}$-activities (e.g., modern versus aged).

Before extrapolating the results from the few SMRS studied to a global scale, it is important to determine whether they are representative of all SMRS (e.g., Raymond et al. 2004). For example, erosion and transport of soil organic carbon is thought to promote oxidation rates (Lal 2003). Hence, one possible consequence of the mobilization of ancient POM by SRMS is the enhanced oxidative degradation of otherwise unreactive organic carbon sequestered on land over geological time scales. Although the fate of land-derived POM exported by rivers is still an open question (e.g., Aller and Blair 2004; Goñi et al. 2005a, 2008; Blair et al. 2004; Galy et al. 2008), such an interpretation implies that SMRS may represent a net source of aged/fossil $\mathrm{CO}_{2}$. Furthermore, the relative paucity of biogenic POM exported by SMRS could be interpreted to indicate that these watersheds contain poorly developed soils that provide a negligible sink for atmospheric $\mathrm{CO}_{2}$. According to this interpretation, tectonically active SMRS may primarily contribute mineral material to the ocean, exporting little biogenic terrestrial POM relative to large river systems with well-developed soils and extensive floodplains (e.g., Smith et al. 2001;
Blair et al. 2004). Notably, the mineral material supplied by SMRS may enhance the sequestration of autochthonous POM in depositional centers (deltas/ shelves) by producing rapid burial rates and abundant mineral surfaces, both of which can minimize postdepositional degradation (e.g., Hartnett et al. 1998; Mayer 1994). These effects may be most significant in SMRS because they are characterized by high temporal coherence between elevated discharges and energetic ocean conditions that favor rapid deposition and efficient burial (e.g., Wheatcroft et al. 2010).

Recent findings raise questions regarding the concept of a simple bimodal distribution (fossil versus modern) of POM in SMRS. For example, Leithold et al. (2006) showed that most of the carbon in the suspended load from SRMS characterized by low sediment yields was modern in age. Furthermore, Drenzek et al. (2009) and Wakeham et al. (2009) found that the ages of biomarkers specific to vascular plants (i.e., long-chain fatty acids and n-alkanes) in sediments from the Eel River margin were significantly greater than those expected from a purely modern source, suggesting contributions from preaged biogenic sources with extended residence times in the watershed. Hilton et al. (2008b) measured an increase in the $\Delta^{14} \mathrm{C}$ of suspended POM in the LiWu River in Taiwan during a typhoon-triggered flood, suggesting export of non-fossil, biogenic carbon by this tropical SRMS is likely to be higher than previously realized. Collectively, these studies suggest that the processes responsible for particle transport in SMRS systems, which are highly dependent on discharge, mobilize a variety of organic matter types of different sources and diagenetic histories. Such a realization contrasts with the current paradigm that modern biogenic carbon is primarily mobilized by surface erosion processes during low discharges, whereas fossil carbon is mobilized primarily by deeper erosive processes (e.g., landslides) that dominate at higher discharges (e.g., Masiello and Druffel 2001; Gomez et al. 2003).

The objective of this paper is to investigate in detail how the concentration and composition of POM vary with discharge $(\mathrm{Q})$, the master variable controlling material export in fluvial systems (Wheatcroft et al. 2010). With this objective in mind, we sampled suspended particles from the Alsea River, a SMRS draining the central Oregon Coast Range over a wide range of discharges during the 2008 water year 
(1 October 2007-30 September 2008), which included several flood events of significance magnitude $\left(\mathrm{Q}: \mathrm{Q}_{\text {mean }}>2.5\right)$. In the Alsea, these flood events are responsible for the majority (90\%) of the annual carbon and sediment export by the river (Wheatcroft et al. 2010), a feature shared with most other SMRS. Besides quantifying the concentrations of suspended sediment and POM in the river, we characterized its chemical composition by measuring bulk variables such as molar carbon to nitrogen ratios $(\mathrm{C}: \mathrm{N})$, stable carbon $\left(\delta^{13} \mathrm{C}\right)$ and radiocarbon $\left(\Delta^{14} \mathrm{C}\right)$ isotopic compositions to help elucidate contributions from biogenic versus petrogenic sources. Additionally, we investigated the provenance of biogenic carbon by quantifying the concentration and composition of organic compounds with specific biological sources (i.e., biomarkers). Among the biomarkers measured, we used lignin and cutin products, which are uniquely synthesized by vascular plants, to trace the contributions of vegetation-derived carbon (e.g., Hedges and Mann 1979; Goñi and Hedges 1990a). We also quantified compounds derived from specific amino acids and fatty acids, biochemicals that are enriched in non-vascular plant sources of organic matter (e.g., algae, bacteria and fungi) to trace non-vegetation sources of biogenic carbon (Goñi and Hedges 1995).

To give context to our results from the Alsea River, we have chosen to compare them directly to similar data obtained from the well-studied Santa Clara River (e.g., Masiello and Druffel 2001; Komada et al. 2004, 2005; Warrick and Mertes 2009). The insights derived from the biogeochemical work in this latter system have made a significant impact on our understanding of SMRS and to a large degree provided the impetus for the present study. The Alsea and Santa Clara rivers share several common features, including comparable watershed size and elevation, seasonally-contrasting hydrographs and geographical locations within a temperate coastal climate zone. The two systems also display significant differences in key factors such as tectonic setting, vegetation and discharge, all of which potentially affect the cycling and routing of carbon. A comparison between the two systems, therefore provides an opportunity to test established conceptual models of carbon export by SRMS and provide new insights into this area of biogeochemistry. Overall, this comparison demonstrates that the Santa Clara River, far from being 'a prototypical small mountainous river' (Masiello and Druffel 2001), is part of a continuum of SMRS with contrasting hydroclimate, geology, vegetation and land use. Where appropriate, we extend our comparison to other SMRS such as the temperate Nivelle River draining the schist-dominated Western Pyrenean Mountains (Coynel et al. 2005), the typhoon dominated, wet-tropical rivers of Taiwan (e.g., Kao and Liu 1996; Hilton et al. 2008a, b) and the heavily impacted systems of the North Island of New Zealand (e.g., Gomez et al. 2003).

\section{Materials and methods}

Study area

The Alsea River, located in the central Oregon Coast Range (OCR), drains a rugged, forested landscape (basin area $1,220 \mathrm{~km}^{2}$ ) with a maximal elevation of $1,250 \mathrm{~m}$ (Fig. 1). This region of the OCR has a steep topography with relatively uniform ridge and valley terrain (Roering et al. 2003, 2005). The Alsea watershed is predominantly underlain by sandstone and siltstone of the Eocene Tyee Formation with some intrusive basalt of the Eocene Siletz River and Burpee Formations (Lovell 1969). The OCR has relatively slow uplift rates $\left(\sim 0.1-0.3 \mathrm{~mm}_{\text {year }}{ }^{-1}\right)$ (Kelsey et al. 1996) and is characterized by steep, soil-mantled hillslopes (e.g., Roering et al. 1999; Montgomery 2001). The thickness of soils covering the watershed are variable, but can be up to $2 \mathrm{~m}$ in the unchanneled valleys that are the main location of shallow landslides. These shallow landslides, which incorporate materials from the soil mantle, dominate sediment transport to stream channel networks in this region (Dietrich and Dunne 1978; Benda and Dunne 1997; Almond et al. 2007).

The lush forests covering the OCR are characterized by relatively high rates of net primary productivity $\quad\left(0.82-0.95 \times 10^{6} \mathrm{~kg} \mathrm{C} \mathrm{km}^{-2}\right.$ year $^{-1}$; Van Tuyl et al. 2005). Vegetation is predominantly coniferous, with Douglas-fir (Pseudotsuga menziesii) and western hemlock (Tsuga heterophylla) dominating in the uplands and western hemlock and Sitka spruce (Picea sitchensis) occurring in a narrow coastal strip (Compton et al. 2003). Two deciduous, hardwood species, the nitrogen-fixing red alder (Alnus rubra) and big-leaf maple (Acer macrophyllum) are locally important in frequently disturbed parts of the 

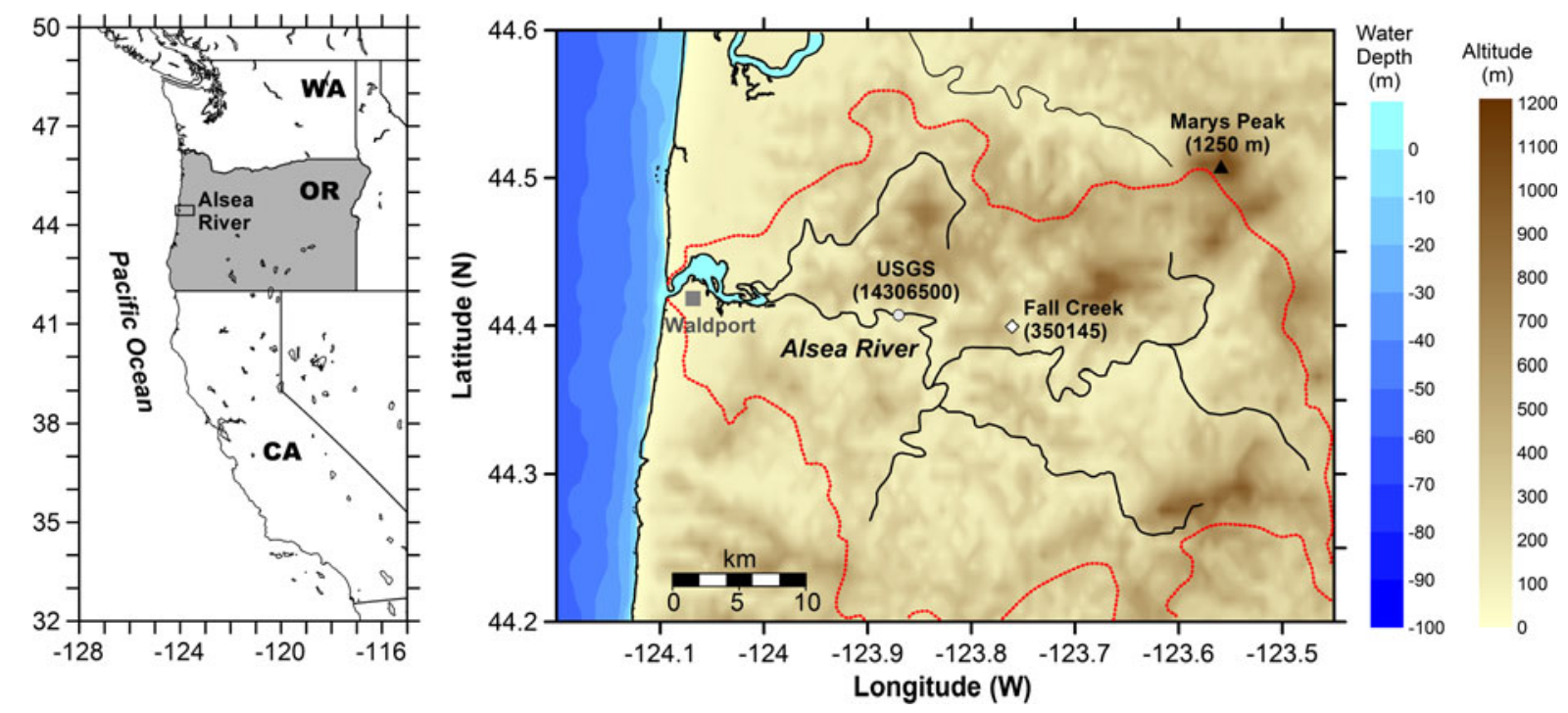

Fig. 1 Maps of the Alsea River basin showing its location in Oregon, its topography and geographical area (red line). The location of specific sites mentioned in the text, including the
USGS river gauging station and the Fall Creek NWS station are indicated on the larger map

of tide and $33.6 \mathrm{~km}$ from the Pacific Ocean and captures drainage from $\sim 70 \%$ of the basin. The USGS has collected nearly continuous measurements of daily discharge at this location since October 1939. In addition, on a daily basis in water years 1974 and 1975 and sporadically thereafter, the USGS and the Oregon Department of Environmental Quality (DEQ) measured suspended sediment concentrations at the gauging station. Based on these records, the Alsea River has a mean discharge of $41.6 \mathrm{~m}^{3} \mathrm{~s}^{-1}$ and an annual sediment yield of $75 \times 10^{3} \mathrm{~kg} \mathrm{~km}^{-2}$ (Wheatcroft and Sommerfield 2005). Historical discharge data show that the Alsea River is an event-dominated river with the typical hydrograph displaying several high-discharge events per year. These peaks in discharge are associated with the passage of winter storms that last a few days.

There are several important differences between the Alsea and Santa Clara River systems (Table 1). The Santa Clara drains an area of southern California that is roughly four times greater than the Alsea River watershed and includes heavily urbanized zones (Ventura, Santa Paula, Fillmore, and Santa Clarita) along the main stem. Unlike the Alsea, several large dams are present in its northern tributaries, which trap sediment and supply water to municipalities and agriculture in the area (Stillwater Sciences 2007). Because of its semi-arid climate, the discharge of the 
Table 1 Comparison of the Alsea River and Santa Clara River watersheds

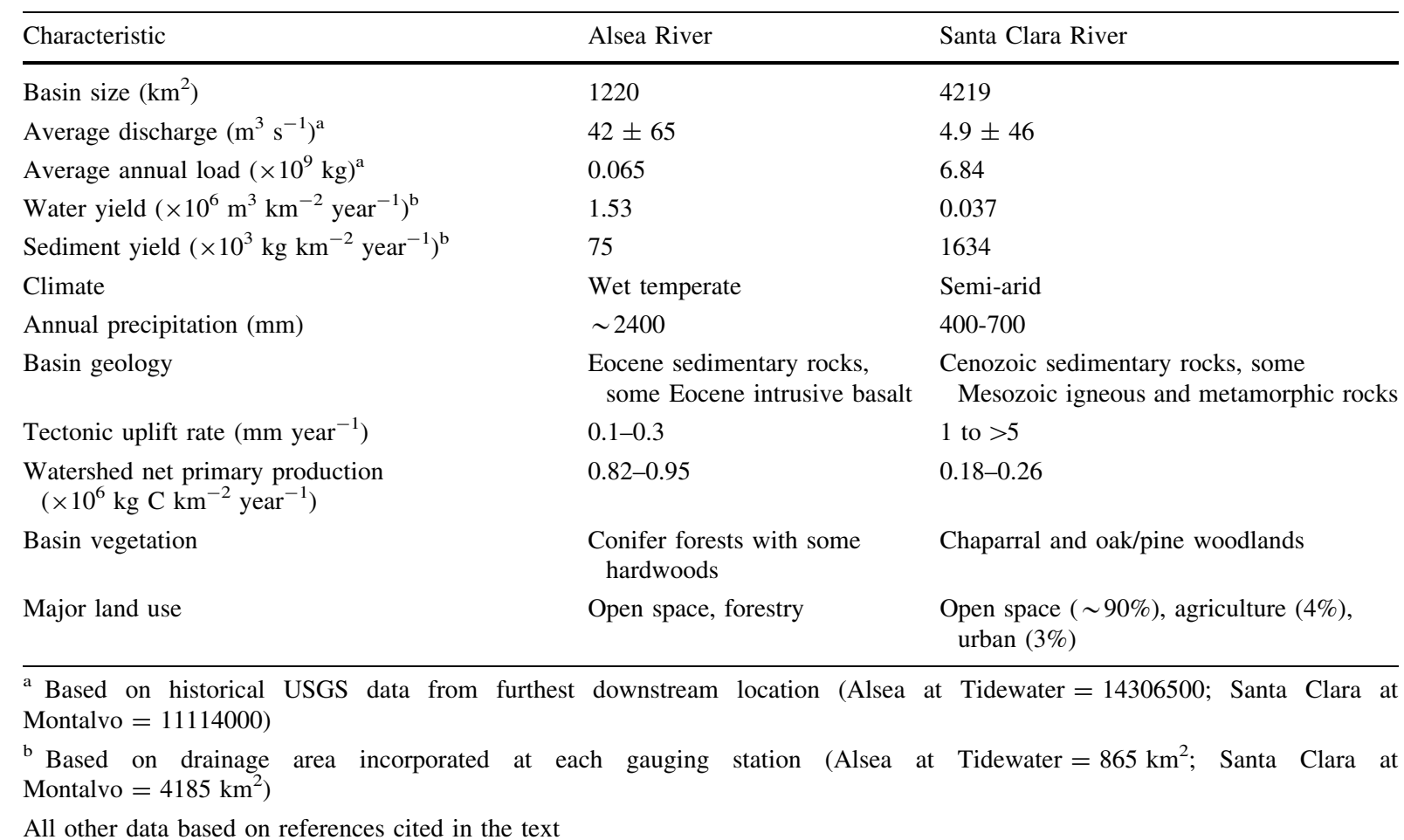

Santa Clara is an order of magnitude lower that of the Alsea River and displays extreme variability that can best be described as 'ephemeral', as zero flows occur $\sim 70 \%$ of the year (Warrick and Mertes 2009). The Santa Clara has an annual sediment load that is two orders of magnitude higher than the Alsea, resulting in an average sediment yield that is $\sim 20$ times greater (Table 1). Several factors contribute to this large contrast in sediment yield. Soft sedimentary rocks, such as shales and mudstones, underlie most of the Santa Clara basin, which is within the Western Transverse Ranges of California. This region of California is characterized by rapid rates of tectonic uplift $\left(>5 \mathrm{~mm} \mathrm{year}^{-1}\right.$ ) that are an order of magnitude greater than those in the Alsea River basin. Furthermore, most $(88 \%)$ of the Santa Clara watershed is covered by native chaparral and woodland vegetation, with relatively low rates of net primary production $\left(0.10-0.26 \times 10^{6} \mathrm{~kg} \mathrm{C} \mathrm{km}^{-2}\right.$ year $^{-1}$; Gray and Schlesinger 1981 and references therein), frequent fires and relatively thin soils (e.g., Warrick 2002; Gabet and Dunne 2003).

The hydroclimate, vegetation and geology of the Santa Clara basin facilitate high erosion rates by processes such as dry ravel, shallow landslides and debris flows (Gabet and Dunne 2003), which can incorporate both soil and bedrock materials and lead to the observed elevated sediment yields (Warrick and Mertes 2009). In contrast, the shallow landslides that dominate the sediment transport processes in the Alsea River basin mobilize primarily soil mantle material, with deep-seated landslides that mobilize bedrock being uncommon (Dietrich and Dunne 1978). In both of these SMRS, sediments from the watershed can be stored temporarily within channel networks and associated floodplains prior to their final delivery to the estuary and the ocean (e.g., Nakamura et al. 2000; Benda and Dunne 1997; Dietrich and Dunne 1978). This temporary storage can lead to further aging and alteration of the organic matter derived from the upland regions of the watershed and to the addition of new organic matter associated with riparian vegetation.

Sample collection and processing

Water samples were collected from the main stem of the Alsea River at a range of discharges (Fig. 2). We sampled from a bridge $\sim 100 \mathrm{~m}$ upstream of the 
Fig. 2 Records of rainfall and discharge in the Alsea River basin for the 2008 water year. a The daily precipitation $(\mathrm{mm})$ measured at the Fall Creek NWS (350145) station. b Hourly discharge $\left(\mathrm{m}^{3} \mathrm{~s}^{-1}\right)$ measured at the USGS gauging station (14306500) with the insert (c) highlighting the largest flood of the season. The sampling dates are denoted in the hydrograph with either black circles or open diamonds. The former indicate occasions when large volume samples were taken. The grey line indicates the flow-level $\left(\mathrm{Q} \sim 100 \mathrm{~m}^{3} \mathrm{~s}^{-1}\right)$ over which $90 \%$ of the annual sediment load is transported by the Alsea River. This level corresponds to 2.5 times the long-term mean discharge $\left(\mathrm{Q}: \mathrm{Q}_{\text {mean }}=2.5\right)$

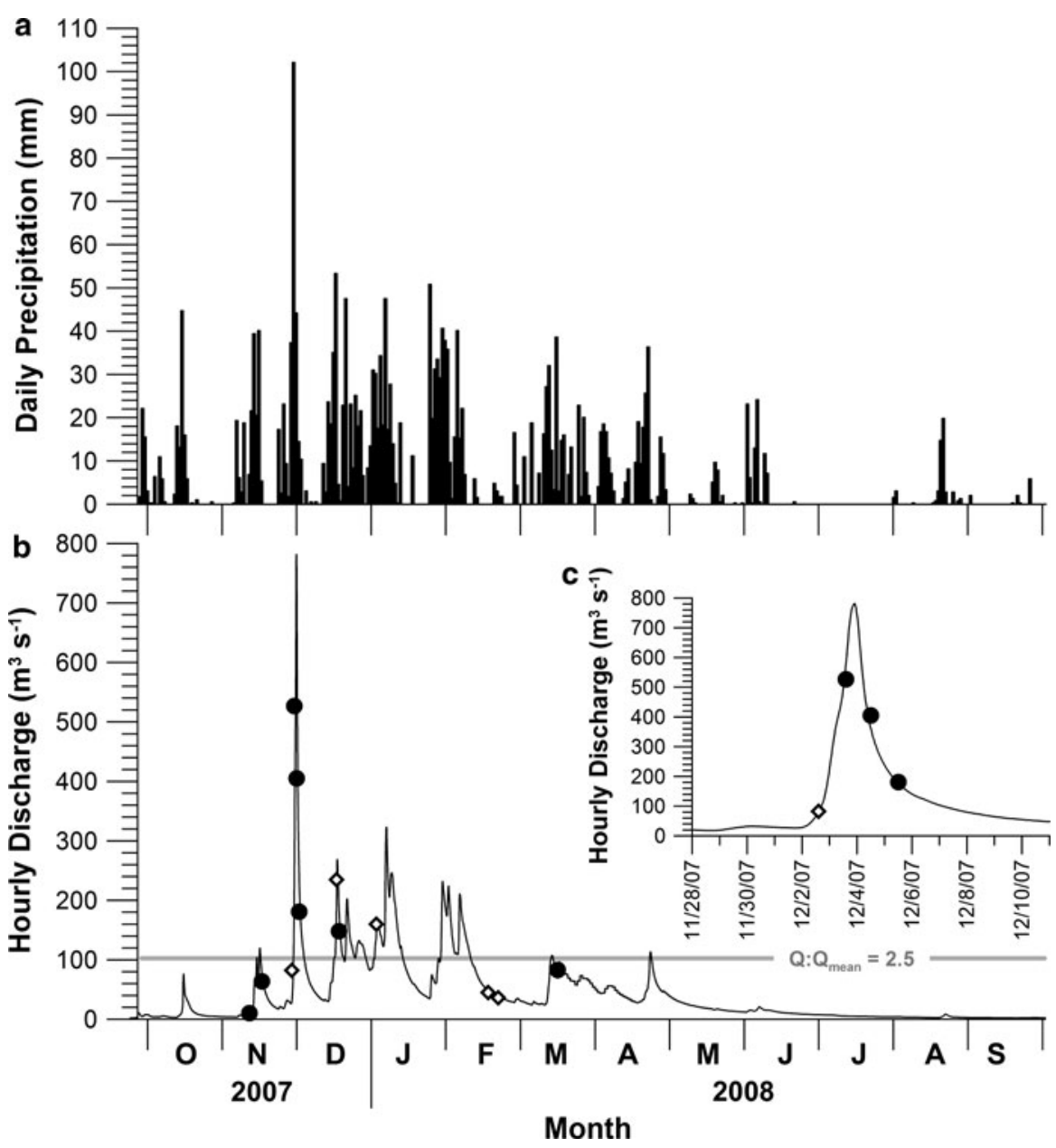

USGS gauging station using a Wildco Horizontal Alpha Sampler that was lowered in the center of the channel and tripped to capture water from $\sim 1 \mathrm{~m}$ below the surface. We collected two types of water samples. First, small-volume water samples were collected in triplicate on each sampling date, placed in acid-rinsed, opaque, 1-1 Nalgene bottles, brought to the lab the same day and filtered onto combusted ( $4 \mathrm{~h}$ at $\left.400^{\circ} \mathrm{C}\right)$ glass fiber filters $(0.7-\mu \mathrm{m}$ pore size). Filters were oven-dried overnight at $60^{\circ} \mathrm{C}$ and weighed to determine the concentration of total suspended sediment (TSS). Second, on selected sampling dates $(n=7)$ when it was logistically feasible, large volume (60 1) samples were collected to isolate gram quantities of suspended materials for detailed geochemical analysis. These larger samples were placed into acidrinsed 20-1 carboys and brought to the laboratory for further processing. Water from the large volume samples was passed through a $63-\mu \mathrm{m}$ sieve to recover coarse suspended particles $(>63 \mu \mathrm{m})$. Fine suspended particles $(<63 \mu \mathrm{m})$ were isolated from the sieved water by centrifugation at $3250 \times g$ for $10 \mathrm{~min}$. After centrifugation, samples were oven-dried at $60^{\circ} \mathrm{C}$ overnight or until constant weights were achieved. This method isolated over $97 \%$ of the suspended solids from most samples. Lower recoveries $(\sim 84 \%)$ were obtained in samples collected during low discharges $\left(\mathrm{Q}<100 \mathrm{~m}^{3} \mathrm{~s}^{-1}\right)$, which were characterized by very low $\left(<15 \mathrm{mg} \mathrm{l}^{-1}\right)$ TSS concentrations.

\section{Chemical analyses}

The concentrations of organic carbon (OC) and nitrogen $(\mathrm{N})$ in all samples were measured via high temperature combustion after removal of inorganic carbonates by vapor phase acidification (e.g., Hedges and Stern 1984; Goñi et al. 2003). The accuracy and precision of these analyses were monitored daily 
through the analysis of multiple standard materials and replicate analyses of selected samples. These analyses consistently showed errors of $<2 \%$ of measured value. We assessed the possibility that some of the nitrogen in the suspended particles may be inorganic by plotting sediment-normalized organic carbon concentrations versus sediment-normalized nitrogen concentrations (e.g., Goñi et al. 2003). These plots (not shown) revealed statistically-significant relationships $\left(\mathrm{r}^{2}=0.98\right)$ between organic carbon and nitrogen concentrations in each particle size class and yielded $y$-intercepts that were not statistically different from zero $(P<0.001)$. Such results indicate all of the nitrogen in these samples is associated with organic carbon and therefore is likely to be organic $(\mathrm{ON})$, as opposed to inorganic nitrogen species such as adsorbed ammonium.

In samples containing enough material, splits of unground fine particles were analyzed for specific mineral surface area (SA) using the Brunauer, Emmett and Teller (BET) technique (e.g., Mayer 1994; Goñi et al. 2005a). Samples were combusted at $300^{\circ} \mathrm{C}$ for $4 \mathrm{~h}$ to remove organic matter and degassed under vacuum at $250^{\circ} \mathrm{C}$ for $1 \mathrm{~h}$ to remove adsorbed water prior to the 5-point BET measurement. The precision and accuracy of the technique was monitored by weekly analyses of standard reference materials and replicate analyses of selected samples, which yielded analytical errors of $<5 \%$ of measured values.

The stable isotopic compositions of OC $\left(\delta^{13} \mathrm{C}\right)$ and ON $\left(\delta^{15} \mathrm{~N}\right)$ in both fine and coarse particles were determined on pre-acidified samples using hightemperature combustion coupled with isotope ratio mass spectrometry (Goñi et al. 2005b) and are reported in the standard delta notation ( $\delta$ in \%o) relative to Pee Dee Belemnite and air standards. Multiple commercially available standard materials of contrasting $\delta^{13} \mathrm{C}$ and $\delta^{15} \mathrm{~N}$ signatures were analyzed daily to calibrate the response of the mass spectrometer over a range of concentrations. The accuracy and reproducibility of the instrument were evaluated daily by analysis of standardized materials (standard compounds and sediment samples) and used to assess the overall precision, which was always better than $\pm 0.3 \%$. Radiocarbon compositions of bulk organic matter in selected samples were determined at the National Ocean Sciences Accelerator Mass Spectrometry (NOSAMS) facility in Woods Hole. Radiocarbon data are reported in the standard $\Delta{ }^{14} \mathrm{C}$ notation and as fraction modern $\left(f_{\text {mod }}\right)$ relative to the 1950 international standard (NBS Oxalic Acid I) and used to calculate the age of the bulk carbon in POM samples (e.g., Stuiver and Polach 1977; Vogel et al. 1987). The analytical variability associated with these AMS analyses translated into an average error in $\mathrm{f}_{\text {mod }}$ of less than $0.5 \%$ of the calculated value.

The fine and coarse fractions of suspended sediments were analyzed by alkaline $\mathrm{CuO}$ oxidation (Goñi and Montgomery 2000; Goñi et al. 2009) to obtain the yields of a variety of products derived from different biochemical precursors and biological sources. The analytical precision and variability of this technique was evaluated by oxidizing well-characterized standardized materials (vegetation and sediment samples) as well as replicate analyses of selected samples. Overall, the variability in the yield of individual compounds ranged from 5 to $15 \%$ of the measured value, with the higher variability associated with compounds with low yields ( $<0.05 \mathrm{mg} \mathrm{g}^{-1}$ sediment). In this study, we quantified several classes of reaction products, including vanillyl phenols $(\mathrm{VP}=$ vanillin + acetovanillone + vanillic acid), syringyl phenols $(\mathrm{SP}=$ syringealdehyde + acetosyringone + syringic acid) and cinnamyl phenols ( $\mathrm{CP}=p$-coumaric acid + ferulic acid) that are characteristically derived from different lignin sources (e.g., Hedges and Mann 1979). Because lignin is uniquely synthesized by vascular land plants (i.e., trees, grasses), lignin-derived products have been widely used to trace organic matter derived from terrigenous vegetation in a variety of environments (e.g., Bianchi et al. 2007; Prahl et al. 1994; Dalzell et al. 2007; Otto and Simpson 2006).

We also quantified several cutin-derived $\mathrm{C}_{16}$ to $\mathrm{C}_{18}$ hydroxy fatty acids (including hydroxyhexadecanedioic acid, dihydroxyhexadecanoic acid and trihydroxyoctacecanoic acid) that make up the chemical backbone of cuticles covering the soft aerial tissues of vascular plants (e.g., needles, leaves; Goñi and Hedges 1990a). Because different types of vascular plants synthesize these compounds in characteristic patterns; cutin acids (CA) provide another unique tracer of vegetationderived carbon in a variety of settings (e.g., Gough et al. 1993; Kastner and Goñi 2003; Sollins et al. 2006; Crow et al. 2009b). Suberin, another aliphatic polymer associated with root tissues of vascular plants, also produces substituted fatty acids (primarily $\omega$-hydroxyhexadecanoic, hexadecanedioic acid, and $\omega$-hydroxyoctadecenoic acid; e.g., Crow et al. 2009a). 
We used the abundance of these latter compounds relative to di- and tri-hydroxylated compounds derived primarily from cutin to evaluate contributions from belowground vascular plant sources (Filley et al. 2008).

In addition to these vascular plant biomarkers, we quantified the yields of benzoic acids (BA $=$ benzoic acid + m-hydroxybenzoic acid $+3,5$-dihydroxybenzoic acid), which are derived from a variety of sources, including tannins and humic substances. These products have been applied in several systems as tracers of organic matter alteration in soils (Prahl et al. 1994; Houel et al. 2006; Otto and Simpson 2006). Lastly, we quantified products derived from specific amino acids (i.e., aspartic acid, glutamic acid, proline and phenylalanine) and from specific fatty acids $\left(\mathrm{C}_{10}\right.$ to $\mathrm{C}_{18}$ normal fatty acids) (Goñi and Hedges 1995). Because of the enhanced protein and lipid content in organisms such as zooplankton, phytoplankton, bacteria and fungi, these amino acid (AA) and fatty acid-derived (FA) products have been used to trace non-vascular plant sources of organic matter in natural systems (e.g., Goñi et al. 2009; Tesi et al. 2008). In this study, we use lignin and cutinderived products to trace vegetation-derived contributions to the suspended load and amino acid and fatty acid-derived products to assess contributions from other sources (algal, microbial). We also investigate the diagenetic state of the organic matter using specific markers (e.g., benzoic acids).

\section{Results}

Discharge and suspended particulate concentrations

The 2008 water year was typical in terms of rainfall and discharge (Fig. 2). Total precipitation measured at the Fall Creek NWS station during that year was $2,360 \mathrm{~mm}$ (within $1 \%$ of long-term average) with $\sim 75 \%$ of that falling between November 2007 and March 2008, a fraction that is essentially the same as the long-term average (74\%). Total water discharge during the 2008 water year amounted to $1.3 \times 10^{9} \mathrm{~m}^{3}$ while the annual mean was $41.5 \pm 58.2 \mathrm{~m}^{3} \mathrm{~s}^{-1}$, both of which were identical to the long term averages. As in most years, roughly $80 \%$ of the discharge occurred during the winter months (November 2007 to March 2008). Daily rainfall records at Fall Creek show the passage of several storm systems from October to April, with the highest daily precipitation (102 mm) on December 2, 2007 (Fig. 2a). Hourly discharge records at the USGS gauging station (Fig. 2b) also show several storm-induced flood events that exceeded $100 \mathrm{~m}^{3} \mathrm{~s}^{-1}\left(\mathrm{Q}: \mathrm{Q}_{\text {mean }}=2.5\right)$. This discharge level is significant because flows above this magnitude are responsible for over $90 \%$ of the particle export (Wheatcroft et al. 2010). The largest seasonal flood coincided with the early December 2007 storm and was characterized by a peak hourly discharge of $781 \mathrm{~m}^{3} \mathrm{~s}^{-1}\left(\mathrm{Q}: \mathrm{Q}_{\text {mean }}=18.8\right)$, which has a return period of 3 years. Close to $200 \mathrm{~mm}$ of rainfall were measured in many areas of the watershed over the 6-day period associated with this event (http://water. weather.gov/precip/). These precipitation intensities are high enough to have triggered shallow landslides (Roering et al. 2003), some of which were evident when we accessed the sampling site.

Our samples were collected over a broad range of discharges (Fig. 2b), ranging from base flow conditions of $11 \mathrm{~m}^{3} \mathrm{~s}^{-1}\left(\mathrm{Q}: \mathrm{Q}_{\text {mean }}=0.3\right)$ to those encountered during the highest flood event (Fig. 2c). The relatively few samples collected over one year, precludes us from investigating seasonal changes in particle compositions and evaluating the effects of sequential flood events on particle loads and characteristics (e.g., Coynel et al. 2005). Nevertheless, because our samples cover a range of $\mathrm{Q}$ and hydrologic conditions (e.g., rising and falling limbs, early and late season), we believe that they are representative of typical winter flows when the majority of sediment and POM is discharged from the Alsea watershed. Our results provide us with the first comprehensive characterization of POM exported by rivers draining the OCR, which can be directly contrasted to the data from the Santa Clara River in southern California, as well as compared to results from other SMRS around the globe.

The concentration of total suspended sediment (TSS), particulate organic carbon (POC) and particulate organic nitrogen (PON) determined from the small-volume water samples ranged from 2.3 to $>340 \mathrm{mg} \mathrm{l}^{-1}$, from 0.15 to $25 \mathrm{mg} \mathrm{l}^{-1}$ and from 0.02 to $1.7 \mathrm{mg} \mathrm{l}^{-1}$, respectively. All concentrations increased as a power function of Q (Fig. 3), with the sample collected at a $\mathrm{Q}$ of $10 \mathrm{~m}^{3} \mathrm{~s}^{-1}$ displaying 
Fig. 3 Concentrations ( $\mathrm{mg}^{-1}$ ) of a total suspended sediment (TSS), b total particulate organic carbon (POC) and c total particulate organic nitrogen $(\mathrm{PON})$ plotted versus discharge $(\mathrm{Q}$, $\mathrm{m}^{3} \mathrm{~s}^{-1}$ ) for the small-volume water samples collected for this study. Error bars illustrate the variability (standard error) associated with replicate samples collected on each occasion. a Historical data on TSS concentrations determined by the USGS and Oregon DEQ (grey crosses). The lines in each graph represent rating curves determined from the data acquired in this study using the "quasi-maximum likelihood estimator" approach described by Cohn et al. (1992) (Eq. 1). The lowest discharge $\left(\mathrm{Q}=11 \mathrm{~m}^{3} \mathrm{~s}^{-1}\right)$ sample was excluded from these calculations. The parameters for each fit are as follows: $\mathbf{a}$ for TSS, $\beta_{0}=-5.96, \beta_{1}=1.87, s=0.287 ; r^{2}=0.97$; $\mathbf{b}$ for POC, $\beta_{0}=-7.26, \beta_{1}=1.60, s=0.574 ; r^{2}=0.87$; $\mathbf{c}$ for PON $\beta_{0}=-8.28, \beta_{1}=1.33, s=0.542 ; r^{2}=0.84$

distinctively elevated values for such low flows. This latter trend is commonly observed in many rivers and suggests the presence of a distinct particle pool (e.g., river algae) at very low, base flows (e.g., Wheatcroft and Sommerfield 2005). Notably, our TSS concentrations are comparable with historical data collected by the USGS and Oregon DEQ during a similarly broad range of discharges (Fig. 3a) suggesting that our sampling protocols were adequate and the samples were representative of a typical year.

Discharge and constituent-specific concentrations were fit with an unweighted, least squares regression of the form:

$\ln C_{i}=\beta_{0}+\beta_{1} \ln Q_{t}+s^{2} / 2$,

where $\beta_{0}$ and $\beta_{1}$ are regression coefficients, $C_{i}$ is the constituent concentration, $Q_{t}$ is the instantaneous discharge and $s$ is the standard error of residuals (e.g., Cohn et al. 1992). This quasi-maximum likelihood method to fit the data corrects for retransformation bias associated with using log linear regressions to calculate loads (e.g., Cohn 1995; Wheatcroft and Sommerfield 2005). Given the relatively few samples collected, the rating curves resulting from these fits should be considered tentative at best (Fig. 3). However, there were marked differences among the rating curve exponents for TSS, POC and PON fits (e.g., $\beta_{1}$ values of $1.87,1.60$ and 1.33 , respectively). These contrasts suggest that different factors and mechanism likely contribute to the mobilization and transport of these constituents at distinct river flows.

Table 2 lists the concentration of sediment, OC, ON and the different biomarker categories associated with the fine and coarse particles isolated from the large-
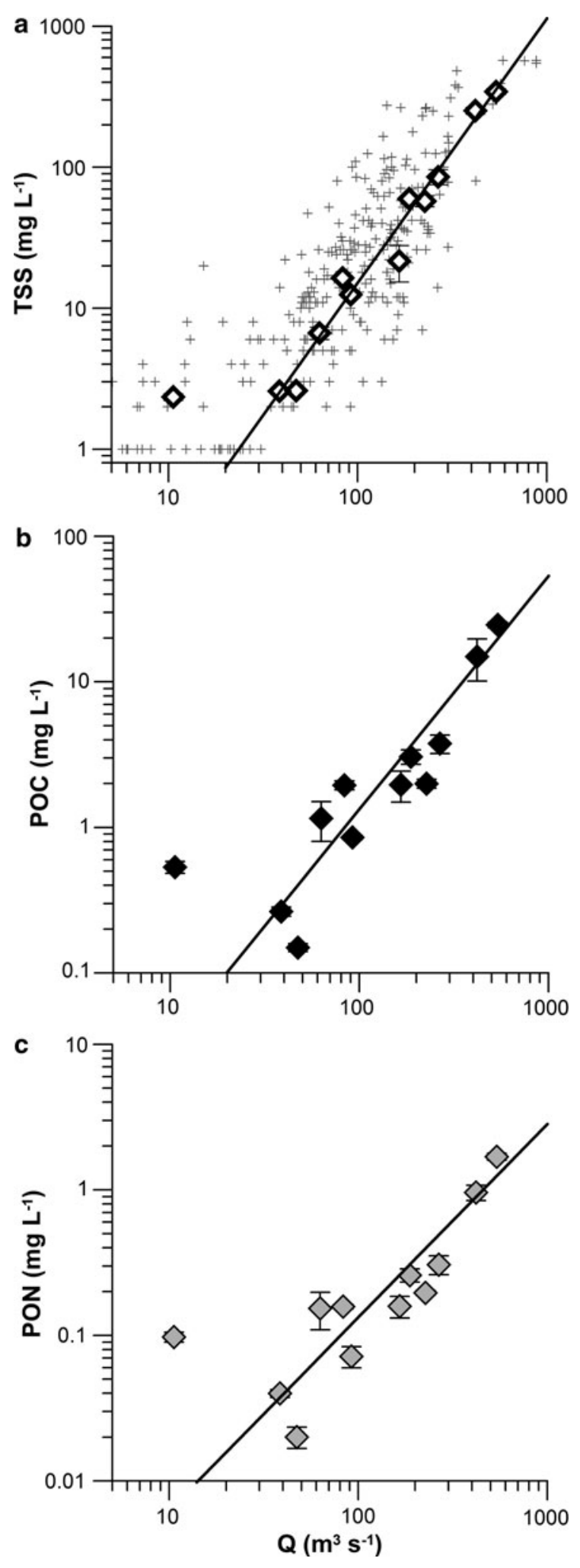
Table 2 Constituent concentrations in fine $(<63 \mu \mathrm{m})$ and coarse $(>63 \mu \mathrm{m})$ particles from the Alsea River

\begin{tabular}{|c|c|c|c|c|c|c|c|c|c|c|c|c|}
\hline Date & $\begin{array}{l}\mathrm{Q} \\
\left(\mathrm{m}^{3} \mathrm{~s}^{-1}\right)\end{array}$ & $\mathrm{Q}: \mathrm{Q}_{\text {mean }}$ & $\begin{array}{l}\text { SS } \\
\left(\mathrm{mg} \mathrm{l}^{-1}\right)\end{array}$ & $\begin{array}{l}\mathrm{OC} \\
\left(\mathrm{mg} \mathrm{1}^{-1}\right)\end{array}$ & $\begin{array}{l}\mathrm{ON} \\
\left(\mathrm{mg} \mathrm{l}^{-1}\right)\end{array}$ & 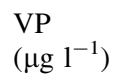 & 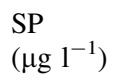 & $\begin{array}{l}\mathrm{CP} \\
\left(\mu \mathrm{g}^{-1}\right)\end{array}$ & $\begin{array}{l}\mathrm{CA} \\
\left(\mu \mathrm{g} \mathrm{1^{-1 }}\right)\end{array}$ & 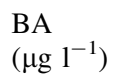 & $\begin{array}{l}\mathrm{AA} \\
\left(\mu \mathrm{g} \mathrm{1^{-1 }}\right)\end{array}$ & $\begin{array}{l}\mathrm{FA} \\
\left(\mu \mathrm{g} \mathrm{1^{-1 }}\right)\end{array}$ \\
\hline \multicolumn{13}{|c|}{ Fine particles $(<63 \mu \mathrm{m})$} \\
\hline $11 / 15 / 07$ & 11 & 0.3 & 1.3 & 0.20 & 0.02 & 3.06 & 1.31 & 0.26 & 1.16 & 0.86 & 11.2 & 0.97 \\
\hline $11 / 20 / 07$ & 63 & 1.5 & 4.0 & 0.37 & 0.04 & 8.70 & 4.38 & 0.74 & 3.71 & 1.03 & 9.28 & 1.21 \\
\hline 03/18/08 & 92 & 2.2 & 8.0 & 0.52 & 0.04 & 21.4 & 5.78 & 0.96 & 4.43 & 2.56 & 23.6 & 1.89 \\
\hline $12 / 05 / 07$ & 187 & 4.5 & 47.8 & 1.47 & 0.12 & 54.8 & 15.8 & 2.88 & 9.15 & 6.70 & 52.0 & 7.74 \\
\hline $12 / 20 / 07$ & 226 & 5.4 & 51.4 & 1.32 & 0.11 & 40.1 & 11.3 & 2.72 & 8.47 & 6.49 & 64.2 & 4.79 \\
\hline $12 / 04 / 07$ & 419 & 10.0 & 70.5 & 1.84 & 0.14 & 58.1 & 14.7 & 4.06 & 11.3 & 6.72 & 50.2 & 5.43 \\
\hline $12 / 03 / 07$ & 539 & 12.8 & 247 & 12.8 & 0.93 & 483 & 150 & 27.6 & 92.7 & 52.8 & 418 & 46.9 \\
\hline \multicolumn{13}{|c|}{ Coarse particles $(>63 \mu \mathrm{m})$} \\
\hline $11 / 15 / 07$ & 11 & 0.3 & 0.46 & 0.14 & 0.01 & n.e. & n.e. & n.e. & n.e. & n.e. & n.e. & n.e. \\
\hline $11 / 20 / 07$ & 63 & 1.5 & 1.38 & 0.22 & 0.01 & 8.45 & 4.57 & 1.04 & 5.95 & 0.86 & 8.73 & 0.72 \\
\hline 03/18/08 & 92 & 2.2 & 5.13 & 0.39 & 0.02 & 16.7 & 6.89 & 1.19 & 6.78 & 1.47 & 4.39 & 2.05 \\
\hline $12 / 05 / 07$ & 187 & 4.5 & 21.8 & 1.53 & 0.07 & 91.8 & 30.3 & 4.90 & 18.1 & 5.94 & 53.7 & 3.19 \\
\hline $12 / 20 / 07$ & 226 & 5.4 & 29.8 & 1.12 & 0.06 & 57.5 & 22.9 & 3.71 & 12.7 & 4.50 & 38.9 & 3.57 \\
\hline $12 / 04 / 07$ & 419 & 10.0 & 156 & 9.60 & 0.50 & 577 & 221 & 28.4 & 93.5 & 37.3 & 267 & 45.4 \\
\hline $12 / 03 / 07$ & 539 & 12.8 & 150 & 11.4 & 0.57 & 669 & 253 & 35.3 & 138 & 45.4 & 349 & 44.7 \\
\hline
\end{tabular}

$Q$ discharge, $S S$ suspended sediments, $O C$ organic carbon, $O N$ organic nitrogen, $V P$ vanillyl phenols, $S P$ syringyl phenols, $C P$ ligninderived cinnamyl phenols, $C A$ cutin acids, $B A$ benzoic acid-derived products, $A A$ amino acid-derived products, $F A$ fatty acid-derived products, n.e. not enough material recovered for measurement

volume samples. Suspended sediment concentrations for the fine and coarse fractions ranged from 1 to $\sim 250 \mathrm{mg} \mathrm{l}^{-1}$ and from 0.5 to $\sim 160 \mathrm{mg} \mathrm{l}^{-1}$, respectively. In the case of $\mathrm{OC}$, fine-fraction concentrations ranged from 0.2 to $13 \mathrm{mg} \mathrm{l}^{-1}$ whereas coarse-fraction concentrations ranged from 0.1 to $11 \mathrm{mg} \mathrm{L}^{-1}$. Among the $\mathrm{CuO}$ reaction products, lignin-derived vanillyl phenols (VP) displayed the highest concentrations, which ranged from 3 to $\sim 480 \mu \mathrm{g} \mathrm{l}^{-1}$ and from 8 to $\sim 670 \mu \mathrm{g} \mathrm{l}^{-1}$ for the fine and coarse fraction, respectively. The next most abundant $\mathrm{CuO}$ class was the amino acid-derived products (AA), which ranged in concentration between 11 and $418 \mu \mathrm{g}^{-1}$ for the fine fraction and from 4 to $\sim 350 \mu \mathrm{g} \mathrm{l}^{-1}$ for the coarse fraction. Cinnamyl phenols (CP) displayed the lowest concentrations of all $\mathrm{CuO}$ reaction product classes with concentrations in the fine fraction of $0.3-28 \mu \mathrm{g}^{-1}$ and of $1-35 \mu \mathrm{g}^{-1}$ in the coarse fraction.

As with TSS, total POC and $\mathrm{PN}$, all $\mathrm{CuO}$ product classes displayed concentrations that increased as power function of $\mathrm{Q}$ but did so with distinct trends (Fig. 4). Because we only determined biomarker concentrations for a few samples, it is difficult to calculate statistically meaningful rating curves for the
$\mathrm{CuO}$ reaction products measured in this study. Instead, we can compare concentration differences between peak and base flows. For example, the combined yields of lignin-derived vanillyl phenols during the highest discharge sample (12/03/07; $\mathrm{Q}=539 \mathrm{~m}^{3} \mathrm{~s}^{-1}$ ) were over 370 times higher relative to those measured during the lowest flow (11/15/07; $\mathrm{Q}=11 \mathrm{~m}^{3} \mathrm{~s}^{-1}$ ). In the case of other vascular plantderived biomarkers (Fig. 4a), such as syringyl and cinnamyl phenols and cutin acids, peak to base flow concentration ratios were somewhat lower $(\sim 300$, 240, 200), but still exceeded the ratio displayed by suspended sediments (150). Non-vascular plant biomarkers, such as fatty acid and amino acid products (Fig. 4b), displayed even lower peak to base flow ratios (94 and 68, respectively). In the case of OC and $\mathrm{ON}$, the concentrations at peak Q were only 46 and 17 times greater than at the lowest Q. Such contrasts suggest distinct entrainment and transport mechanisms for different constituents of the particulate load.

One way to address this issue further is by investigating the role that different-sized particles have in the transport of different constituents of the suspended load. To do this, we calculated the 

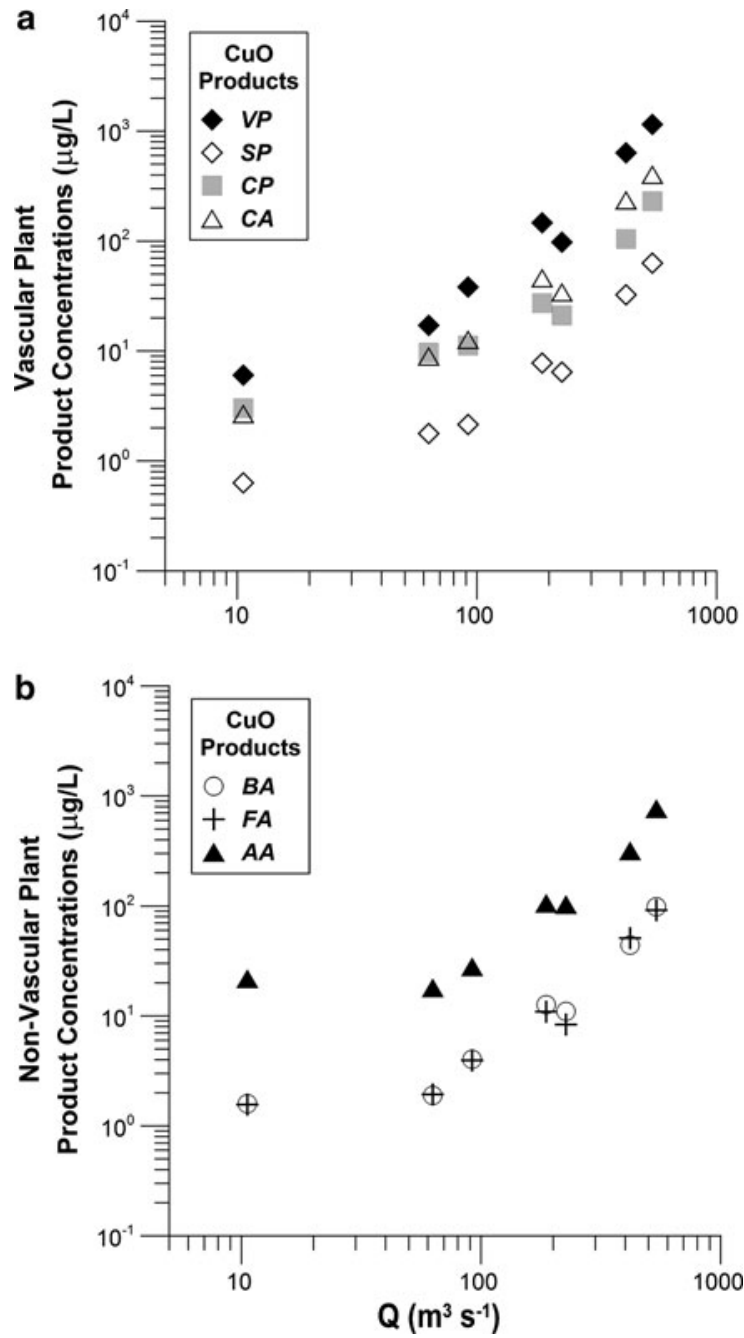

Fig. 4 Concentrations $\left(\mu \mathrm{g} \mathrm{l}^{-1}\right)$ of $\mathrm{CuO}$ product classes plotted versus discharge $\left(\mathrm{Q}, \mathrm{m}^{3} \mathrm{~s}^{-1}\right)$ for the large-volume water samples collected for this study. a Data for the vascular plant products, including vanillyl phenols (VP), syringyl phenols (SP), cinnamyl phenols (CP) and cutin acids (CA). b Data for non-vascular plant products, including amino benzoic acids (BA), amino acid-derived products (AA) and fatty acids (FA)

percentage of each particulate constituent transported in the fine fraction (\%fine) using the following equation:

$\%$ ine $=\frac{f C}{(f C+c C)} \times 100$

where $f C$ and $c C$ are the concentrations of fine and coarse constituents, respectively. Figure 5a illustrates the results of these calculations for four different constituents (SS, OC, CA and AA) as a function of Q. As it can be seen from this graph, with the exception of the samples collected on December 4, 2007 (marked with*), \%fine values for these (and all other) constituents were for the most part independent of Q. It is unclear why coarse particles comprise such a large fraction of the suspended load in the December 4 sample, which was collected during the falling limb of the largest flood that year (Fig. 2c). Further insight into this issue necessitates more frequent sampling of a flood event in order to understand if and how processes such as hysteresis may affect suspended particle compositions (e.g., Coynel et al. 2005).

Although the \%fine values for any given constituent did not change appreciably with $\mathrm{Q}$, there were significant differences among constituents in terms of what proportion of their total load was transported by fine particles (Fig. 5b). For example, on average, fine particles accounted for over $65 \%$ of the SS and OC transported by the Alsea River, whereas they only contributed to $\sim 40 \%$ of the biomarker classes originating from vegetation sources (i.e., lignin derived phenols and cutin acids). In contrast, other biomarker classes (benzoic acids, amino acid-derived and fatty acid-derived products) with important nonvegetation sources (e.g., algae, bacteria) were primarily $(\sim 60 \%)$ transported by fine particles. These data highlight contrasts in the transport of particulate constituents by SMRS (e.g., Coynel et al. 2005) and suggest different biogenic components may have distinct routing mechanisms and residence times within the watershed.

Bulk composition of suspended particulates

Elemental and isotopic compositions of coarse and suspended particles isolated from the large volume samples collected in the Alsea River are presented in Table 3. The weight percent OC contents (\%OC) of fine particles ranged from 3 to $16 \mathrm{wt} \%$ and were significantly lower than the \%OC values of coarse particles $(t$-test; $P<0.05)$, which ranged from 4 to $31 \mathrm{wt} \%$. Weight percent organic nitrogen contents $(\% \mathrm{ON})$ of fine and coarse particles ranged from 0.2 to $1.8 \mathrm{wt} \%$ and from 0.2 to $2.6 \mathrm{wt} \%$, respectively. However, unlike \%OC, there was no significant difference between the $\% \mathrm{ON}$ content of fine and coarse particles. Both \%OC and \%ON contents of fine and coarse particles displayed negative correlations with discharge $\left(\mathrm{r}^{2}>0.8 ; P<0.01\right)$, with values reaching minima at $\mathrm{Q}>200 \mathrm{~m}^{3} \mathrm{~s}^{-1}$ (Table 3). 

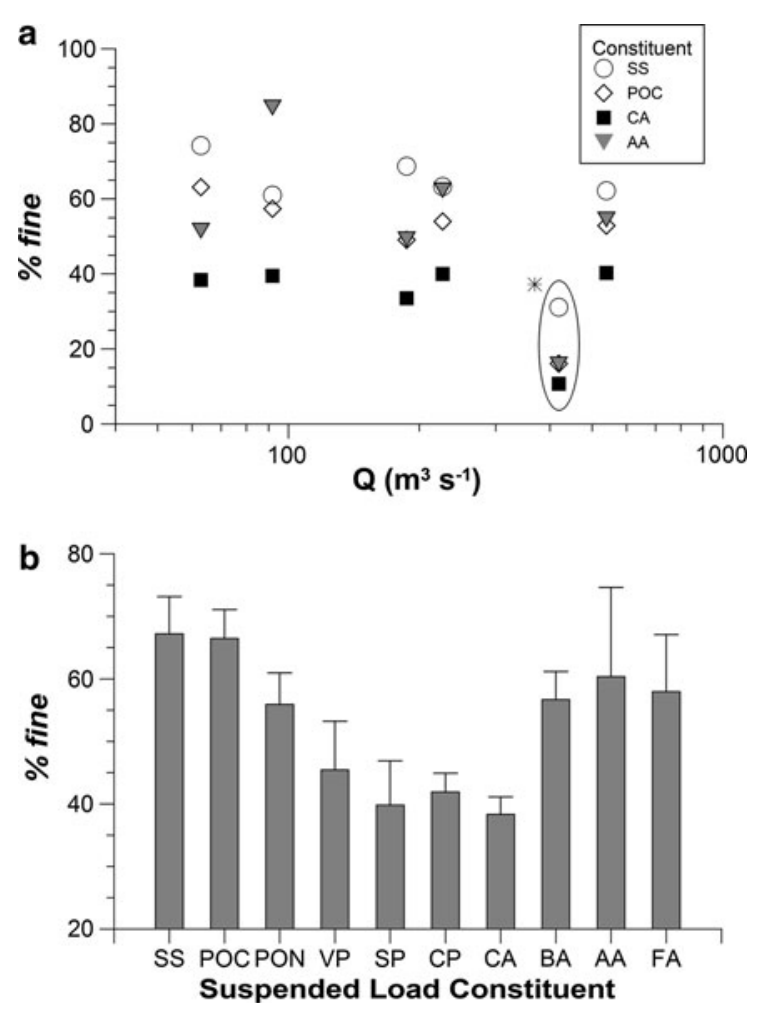

Fig. 5 a Proportion fine values calculated for selected constituents as a function of discharge (Q) and $\mathbf{b}$ average (plus standard deviation) proportion fine values for all constituents measured. The encircled samples marked with * were excluded in the calculation of average proportion fine values. Constituent abbreviations include: $S S$ suspended sediments, $P O C$ particulate organic carbon, $P O N$ particulate organic nitrogen, $V P$ vanillyl phenols, $S P$ syringyl phenols, $C P$ cinnamyl phenols, $C A$ cutin acids, $B A$ benzoic acid-derived products, $A A$ amino acid-derived products, $F A$ fatty acidderived products

These data illustrate the significant decrease in organic matter content of suspended particles from the Alsea River as flows increase. We measured the mineral surface area of five fine particulate samples and found no statistical differences among them, indicating the differences in \%OC among fine particles collected at elevated flows were not likely due to contrasts in grain size. However, we did not recover enough material to allow SA measurements in samples collected at $Q$ values $<90 \mathrm{~m}^{3} \mathrm{~s}^{-1}$ and, hence, cannot rigorously evaluate this explanation during low discharge periods.

Several parameters, including molar carbon to nitrogen ratios $(\mathrm{C}: \mathrm{N})$, stable carbon and nitrogen isotopic compositions ( $\delta^{13} \mathrm{C}$ and $\delta^{15} \mathrm{~N}$, respectively) and radiocarbon compositions $\left(\Delta^{14} \mathrm{C}\right)$, were used to characterize the bulk compositions of fine and coarse POM (Table 3). Fine particles exhibited C:N values that ranged from 10 to 16 and were on average significantly lower than those from coarse particles, which displayed values ranging from 14 to 25 . The $\mathrm{C}: \mathrm{N}$ compositions of both fine and coarse particles were positively correlated with discharge $\left(\mathrm{r}^{2}>0.7\right.$; $P<0.01$ ), indicating that as particle concentrations increased with increasing river flows the POM became increasingly enriched in carbon relative to nitrogen.

The $\delta^{13} \mathrm{C}$ composition of organic matter in fine and coarse particles ranged from -24.5 to $-26.4 \%$ and -26.5 to $-27.5 \%$, respectively (Table 3 ). In the case of ${ }^{15} \mathrm{~N}$ compositions, fine POM exhibited $\delta^{15} \mathrm{~N}$ values that ranged from 1.6 to $5.1 \%$ whereas the $\delta^{15} \mathrm{~N}$ of coarse POM ranged from 0.3 to $1.5 \%$. In general, $\delta^{13} \mathrm{C}$ and $\delta^{15} \mathrm{~N}$ compositions of both fine and coarse POM fractions were significantly enriched during low flows $\left(\mathrm{Q}<90 \mathrm{~m}^{3} \mathrm{~s}^{-1}\right)$ relative to the compositions measured during high flows. Overall, fine POM was significantly enriched ( $t$-test; $P<0.01$ ) in both ${ }^{13} \mathrm{C}$ and ${ }^{15} \mathrm{~N}$ relative to coarse POM. These trends suggest there were differences in source and degradative history of these materials during different river-flow regimes.

The $\Delta^{14} \mathrm{C}$ composition of fine POM ranged from -37.4 to $5.2 \%$ and were slightly ( $t$-test; $P=0.1$ ), depleted relative to those from coarse POM $\left(\Delta^{14} \mathrm{C}=23\right.$ to $31 \%$; Table 3$)$. These results indicate that virtually all of the organic matter present in the Alsea River samples analyzed was modern $\left(f_{\text {mod }} \geq 1.0\right)$ and had an average age of less than 60 years $\left(f_{\text {mod }}=1\right.$ for 1950 standard). These findings include all three samples collected during the largest flood event of the season in early December 2007 (Fig. 2). The only exception was the fine particle sample collected on December 20, 2007 (Q/ $\mathrm{Q}_{\text {mean }}=5.4$ ), which had a $\mathrm{f}_{\text {mod }}$ value of 0.97 that translates into an average age of 250 years. Unlike the $\% \mathrm{OC}$ and $(\mathrm{C}: \mathrm{N})$ parameters, the stable and radioisotopic compositions of carbon in POM showed no statistical trends with Q.

Biomarkers yields

The OC-normalized yields of $\mathrm{CuO}$ reaction products from fine and coarse particles are presented in Table 4, while the combined (fine + coarse) yields 
Table 3 Bulk composition of fine $(<63 \mu \mathrm{m})$ and coarse $(>63 \mu \mathrm{m})$ particles from the Alsea River

\begin{tabular}{|c|c|c|c|c|c|c|c|c|c|}
\hline Date & $\mathrm{Q}\left(\mathrm{m}^{3} \mathrm{~s}^{-1}\right)$ & $\% \mathrm{OC}(\mathrm{wt} \%)$ & $\% \mathrm{ON}(\mathrm{wt} \%)$ & $\mathrm{SA}\left(\mathrm{m}^{2} \mathrm{~g}^{-1}\right)$ & $\mathrm{C} / \mathrm{N}$ (mol:mol) & $\delta^{13} \mathrm{C}(\%)$ & $\delta^{15} \mathrm{~N}(\% \mathrm{o})$ & $\Delta^{14} \mathrm{C}(\%)$ & $f_{\text {mod }}$ \\
\hline \multicolumn{10}{|c|}{ Fine particles $(<63 \mu \mathrm{m})$} \\
\hline $11 / 15 / 07$ & 11 & 15.8 & 1.80 & n.e. & 10 & -24.5 & 5.1 & n.m. & n.m. \\
\hline $11 / 20 / 07$ & 63 & 9.2 & 0.99 & n.e. & 11 & -25.1 & 4.7 & 5.2 & 1.01 \\
\hline 03/18/08 & 92 & 6.5 & 0.55 & 32 & 14 & -26.4 & 1.6 & n.m. & n.m. \\
\hline $12 / 05 / 07$ & 187 & 3.1 & 0.25 & 30 & 14 & -25.5 & 2.8 & n.m. & n.m. \\
\hline $12 / 20 / 07$ & 226 & 2.6 & 0.22 & 31 & 14 & -25.6 & 3.0 & -37.4 & 0.97 \\
\hline $12 / 04 / 07$ & 419 & 2.6 & 0.20 & 30 & 15 & -25.3 & 2.6 & -6.4 & 1.00 \\
\hline $12 / 03 / 07$ & 539 & 5.2 & 0.38 & 32 & 16 & -25.9 & 1.6 & 32.5 & 1.04 \\
\hline \multicolumn{10}{|c|}{ Coarse particles $(>63 \mu \mathrm{m})$} \\
\hline $11 / 15 / 07$ & 11 & 30.8 & 2.56 & n.e. & 14 & n.e. & n.e. & n.e. & n.e. \\
\hline $11 / 20 / 07$ & 63 & 15.6 & 0.97 & n.e. & 19 & -26.5 & 1.5 & 22.9 & 1.03 \\
\hline 03/18/08 & 92 & 7.6 & 0.40 & n.m. & 22 & -27.5 & 0.5 & n.m. & n.m. \\
\hline $12 / 05 / 07$ & 187 & 7.0 & 0.32 & n.m. & 25 & -26.6 & 0.4 & n.m. & n.m. \\
\hline $12 / 20 / 07$ & 226 & 3.8 & 0.20 & n.m. & 21 & -26.6 & 0.6 & 26.9 & 1.03 \\
\hline $12 / 04 / 07$ & 419 & 6.2 & 0.32 & n.m. & 22 & -26.5 & 0.7 & 24.7 & 1.03 \\
\hline $12 / 03 / 07$ & 539 & 7.6 & 0.38 & n.m. & 23 & -26.9 & 0.3 & 30.6 & 1.04 \\
\hline
\end{tabular}

$\% O C$ weight percent organic carbon content, \%ON weight percent organic nitrogen content, $S A$ mineral surface area, $\delta^{13} \mathrm{C}$ stable isotopic composition of organic carbon, $\delta^{15} \mathrm{~N}$ stable isotopic composition of organic nitrogen, $\Delta^{14} \mathrm{C}$ radiocarbon isotopic composition of organic carbon, $f_{m o d}$ fraction of organic carbon modern, n.e. not enough sample for analyses, n.m. not measured

are illustrated in Fig. 6. Vanillyl phenol yields ranged from 1.5 to over $4.0 \mathrm{mg} 100 \mathrm{mg} \mathrm{OC}^{-1}$ and 0.3 to $\sim 13 \mathrm{mg} 100 \mathrm{mg} \mathrm{OC}^{-1}$ in fine and coarse particles, respectively. Syringyl and cinnamyl phenols displayed narrower ranges in their OC-normalized yields, which varied from 0.6 to 1.2 and 0.1 to $0.2 \mathrm{mg} 100 \mathrm{mg} \mathrm{OC}^{-1}$ in fine particles. The yields of these lignin-derived products in coarse particles ranged from 1.8 to 2.3 and 0.3 to $0.4 \mathrm{mg}$ $100 \mathrm{mg} \mathrm{OC}^{-1}$, respectively (Table 4). Cutin acid yields also exhibited relatively narrow variability among fine particle $\left(0.6-1.0 \mathrm{mg} 100 \mathrm{mg} \mathrm{OC}^{-1}\right)$, with broader ranges in coarse particles (1.0-2.8 mg $100 \mathrm{mg} \mathrm{OC}{ }^{-1}$ ). All of these vascular plant-derived biomarkers had in common the fact that coarse particles exhibited significantly $(P<0.02)$ greater OC-normalized yields than their fine counterparts, consistent with higher contribution of lignin and cutin to the larger-sized POM. In contrast, the other three biomarker classes (i.e., benzoic acid-, amino acidand fatty acid-derived products), which have significant non-vegetation sources (i.e. algae, bacteria, fungi), displayed relatively narrow OC-normalized yields with no significant differences between fine and coarse particles (Table 4).
Among the vegetation biomarkers, the OC-normalized yields of vanillyl phenols exhibited statistically significant increases with increasing Q (Fig. 6a). Syringyl phenols also showed a Q-related increase in their yields, albeit it was less statistically significant (Fig. 6b). The OC-normalized yields of cinnamyl phenols did not vary as a function of $\mathrm{Q}$ (Fig. 6c). However, because of the predominance of vanillyl phenols, the overall lignin yields $(\Lambda=$ $\mathrm{VP}+\mathrm{SP}+\mathrm{CP}$; Hedges and Mann 1979) in these samples were positively correlated with $\mathrm{Q}$, with the highest lignin contents measured at the highest flows (Fig. 6d). In contrast, the OC-normalized yields of cutin acids, another vegetation marker specific to vascular plant cuticles, displayed opposite trends with decreasing values at increased flows (Fig. 6e). The contrasts between these two macromolecules indicate marked differences in the character and transport of vegetation-derived POM (i.e., woody versus nonwoody plant matter) as a function of discharge. Examination of the individual hydroxylated fatty acid data showed compounds with a predominant suberin origin (e.g., Crow et al. 2009a) accounted for less than $10 \%$ of combined hydroxyfatty acid yields measured. Furthermore, all fine and coarse samples 
Table 4 Carbon-normalized yields (mg $100 \mathrm{mg} \mathrm{OC}^{-1}$ ) of $\mathrm{CuO}$ product classes in fine $(<63 \mu \mathrm{m})$ and coarse $(>63 \mu \mathrm{m})$ particles from the Alsea River

\begin{tabular}{|c|c|c|c|c|c|c|c|c|}
\hline \multirow[t]{2}{*}{ Date } & \multirow{2}{*}{$\begin{array}{l}\mathrm{Q} \\
\left(\mathrm{m}^{3} \mathrm{~s}^{-1}\right)\end{array}$} & \multicolumn{7}{|c|}{$\mathrm{CuO}$ biomarker classes } \\
\hline & & VP & SP & $\mathrm{CP}$ & $\mathrm{CA}$ & BA & AA & FA \\
\hline \multicolumn{9}{|c|}{ Fine particles $(<63 \mu \mathrm{m})$} \\
\hline $11 / 15 / 07$ & 11 & 1.49 & 0.64 & 0.13 & 0.57 & 0.42 & 5.49 & 0.48 \\
\hline $11 / 20 / 07$ & 63 & 2.36 & 1.19 & 0.20 & 1.01 & 0.28 & 2.52 & 0.33 \\
\hline 03/18/08 & 92 & 4.09 & 1.10 & 0.18 & 0.84 & 0.49 & 4.50 & 0.36 \\
\hline $12 / 05 / 07$ & 187 & 3.72 & 1.08 & 0.20 & 0.62 & 0.45 & 3.53 & 0.53 \\
\hline $12 / 20 / 07$ & 226 & 3.04 & 0.86 & 0.21 & 0.64 & 0.49 & 4.88 & 0.36 \\
\hline $12 / 04 / 07$ & 419 & 3.15 & 0.80 & 0.22 & 0.61 & 0.36 & 2.72 & 0.29 \\
\hline $12 / 03 / 07$ & 539 & 3.78 & 1.17 & 0.22 & 0.72 & 0.41 & 3.27 & 0.37 \\
\hline \multicolumn{9}{|c|}{ Coarse particles $(>63 \mu \mathrm{m})$} \\
\hline $11 / 15 / 07$ & 11 & n.e. & n.e. & n.e. & n.e. & n.e. & n.e. & n.e. \\
\hline $11 / 20 / 07$ & 63 & 3.93 & 2.12 & 0.48 & 2.77 & 0.40 & 4.06 & 0.34 \\
\hline 03/18/08 & 92 & 4.29 & 1.77 & 0.30 & 1.74 & 0.38 & 1.13 & 0.53 \\
\hline $12 / 05 / 07$ & 187 & 6.01 & 1.98 & 0.32 & 1.19 & 0.39 & 3.51 & 0.21 \\
\hline $12 / 20 / 07$ & 226 & 5.12 & 2.04 & 0.33 & 1.13 & 0.40 & 3.47 & 0.32 \\
\hline $12 / 04 / 07$ & 419 & 6.00 & 2.30 & 0.30 & 0.97 & 0.39 & 2.77 & 0.47 \\
\hline $12 / 03 / 07$ & 539 & 5.87 & 2.22 & 0.31 & 1.21 & 0.40 & 3.06 & 0.39 \\
\hline
\end{tabular}

Footnotes as in Tables 2 and 3

displayed dihydroxyhexadecanoic acid/ $\omega$-hydroxyoctadecenoic acid ratios much greater than 60 , indicating most of these hydroxyl fatty acids in the rivers suspended materials originated from above ground tissues (e.g., needles and leaves) rather than below ground (e.g., roots) sources (Filley et al. 2008). All non-vegetation biomarker classes (BA, AA and FA) failed to show any trend with Q (Fig. 6f-h), suggesting that the mobilization of organic matter sources enriched in these products appears to not to be sensitive to the flow regime.

\section{Discussion}

Role of discharge in particulate material transport

Discharge is a key factor controlling the concentrations of particulate materials in most river systems. In the Alsea, concentrations of all particulate constituents, including TSS, total POC, total PON, as well as organic compounds from vegetation and non-vegetation sources, increase as power function of flow (Table 2; Figs. 3, 4). Based on these limited data, there is no clear evidence for supply limitation and dilution of any of these POM constituents at high flows. This observation is important when interpreting discharge-related compositional changes in the particulate load because any change cannot be attributed to concentration decreases but rather to enhanced mobilization of one constituent relative to another. Although our limited observations preclude us from investigating seasonal effects on suspended loads (e.g., Coynel et al. 2005), the rating curves calculated from the TSS, POC and PON data in Fig. 3 illustrate this effect. For example, TSS displays the steepest rise in concentration, and hence the highest rating exponent, followed by $\mathrm{POC}$ and $\mathrm{PON}$. One explanation for such trend is that as flows increase in the system, the river transports increased amounts of mineral rich materials relatively depleted in POC and especially PON. The enhanced erosion of mineral soils with low carbon and nitrogen contents during flood events is consistent with this explanation. The discussion on the composition of POM in the next section will examine this hypothesis more closely.

Before examining POM compositions, it is important to note that not all river systems display particle concentration trends that can be described by power functions of Q. In some rivers, such as those affected by sediment-trapping dams, particle supply to the stream is limited and suspended sediment concentrations are often uncorrelated with discharge (e.g., Syvitski et al. 2000). Furthermore, in many rivers the concentrations of dissolved constituents (nutrients, dissolved organic carbon) are also uncorrelated and/or negatively correlated with discharge (e.g., Hoover and Mackenzie 2009; Howden et al. 2009; Warrick et al. 2005; Masiello and Druffel 2001) as a result of dilution at higher flows. A key consequence of the power function relationship between particulate concentrations and flow in SMRS is the importance of high discharge events in the export of these materials to the ocean. One way to illustrate this point in the Alsea River is to use the preliminary rating curves derived from the TSS, POC and PON data (Fig. 3) and the daily discharge record (Fig. 2) to estimate the impact of seasonal and flood-event export. In 2008 the Alsea transported $1.3 \times 10^{9} \mathrm{~m}^{3}$ of water, $4.8 \times$ $10^{7} \mathrm{~kg}$ of TSS, $3.3 \times 10^{6} \mathrm{~kg}$ of POC and $2.6 \times$ $10^{5} \mathrm{~kg}$ of PON past Tidewater gauge station. The proportion of water, TSS, POC and PON transported during the winter months (November through March) amounted to $80,99,98$ and $97 \%$ of the yearly totals. 
Fig. 6 Organic carbonnormalized yields of different $\mathrm{CuO}$ product classes as a function of discharge (Q). The abbreviations for the $\mathrm{CuO}$ product classes are as indicated in Fig. 4. In addition, $\Lambda$ represents the sum of lignin-derived products $(\mathrm{VP}+\mathrm{SP}+\mathrm{CP})$. The equations for those biomarker classes that display statisticallysignificant fits are included in the graphs
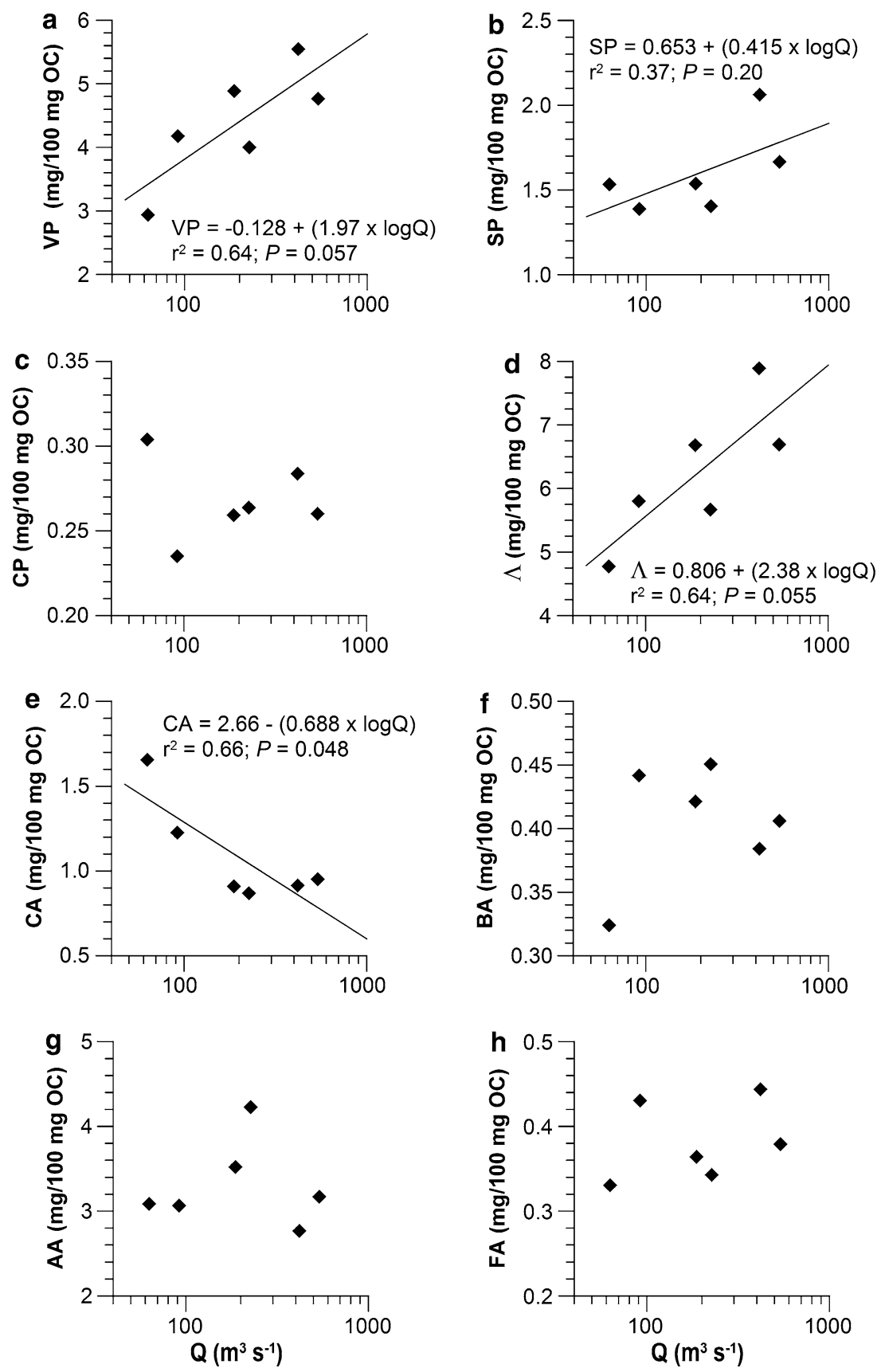

Floods $\left(\mathrm{Q}>100 \mathrm{~m}^{3} \mathrm{~s}^{-1}\right)$ with a $\mathrm{Q}: \mathrm{Q}_{\text {mean }}>2.5$ were responsible for the export of $6.3 \times 10^{8} \mathrm{~m}^{3}$ of water, $4.5 \times 10^{7} \mathrm{~kg}$ of TSS, $3.0 \times 10^{6} \mathrm{~kg}$ of POC and $2.3 \times 10^{5} \mathrm{~kg}$ of PON. In other words, the eight or so floods experienced by the Alsea River during the 2008 water year (Fig. 2) were responsible for 48, 93, 90, and $86 \%$ of the total water, TSS, POC and PON transported that year. Such disproportionate particlebound export during winter-storm induced floods has a fundamental impact in the dispersion and fate of these materials when they enter the ocean and clearly differentiate the Alsea River and other similar SMRS from large river systems (e.g., Wheatcroft et al. 2010). 
Fig. 7 Comparison of different measurements as a function of discharge between Alsea and Santa Clara rivers including a particulate organic carbon (POC) concentrations, b weight percent organic carbon content of suspended particles (\%POC) and $\mathbf{c}$ radiocarbon compositions $\left(\Delta^{14} \mathrm{C}\right)$ of particulate organic matter. Data from the Santa Clara River are from Masiello and Druffel (2001); data from the Alsea River are from this study. The lines in (a) represent rating curves estimated using the "quasi-maximum likelihood estimator" approach described by Cohn et al. (1992) (Eq. 1). The lowest discharge sample (marked with a *) in both the Santa Clara and Alsea data sets was excluded when calculating each of the rating curves. For the Santa Clara River the parameters describing the POC rating curve are as follows: $\beta_{0}=2.06, \beta_{1}=0.609, s=1.04 ; r^{2}=0.80$. For the Alsea River the parameters describing the POC rating curve are as follows: $\beta_{0}=-7.26, \beta_{1}=1.60, s=0.574 ; r^{2}=0.87$

Figure 7a illustrates the relationship between discharge and POC in both the Alsea and Santa Clara Rivers (Masiello and Druffel 2001). Although we have few data available for both systems, these plots illustrate the contrasts between these two systems and provide additional insight into the factors responsible for the mobilization and export of POM by small mountainous rivers. For example, whereas POC concentrations in the Alsea River rise steeply as a power function of discharge, in the Santa Clara River the POC concentration rise is less pronounced and appears to asymptote at high flows. Such trends suggest that, unlike the Alsea River, the transport of POC by the Santa Clara may be supply limited at high flows. The ephemeral nature of this semi-arid river likely is responsible for this trend as elevated flows are never sustained long enough to efficiently transport all the materials entrained in the channel.

Even though the OC content of suspended sediments are much lower in the Santa Clara relative to the Alsea, POC concentrations in the former are much greater (Fig. 7a). This is a direct result of the greatly elevated particle yields in the Santa Clara River (e.g. Table 1), which overwhelm the differences in particle compositions between the two systems. Contrasts in the slope and magnitude of the POC-Q relationship extend to other SMRS with distinct hydroclimate and watershed characteristics (e.g., Kao and Liu 1996; Hilton et al. 2008b; Gomez et al. 2003; Coynel et al. 2005). Unraveling the factors responsible for such contrasts at a global scale is an important objective that is beyond the scope of this paper. However, as we show below, the character and source of POM in the Alsea River indicate that
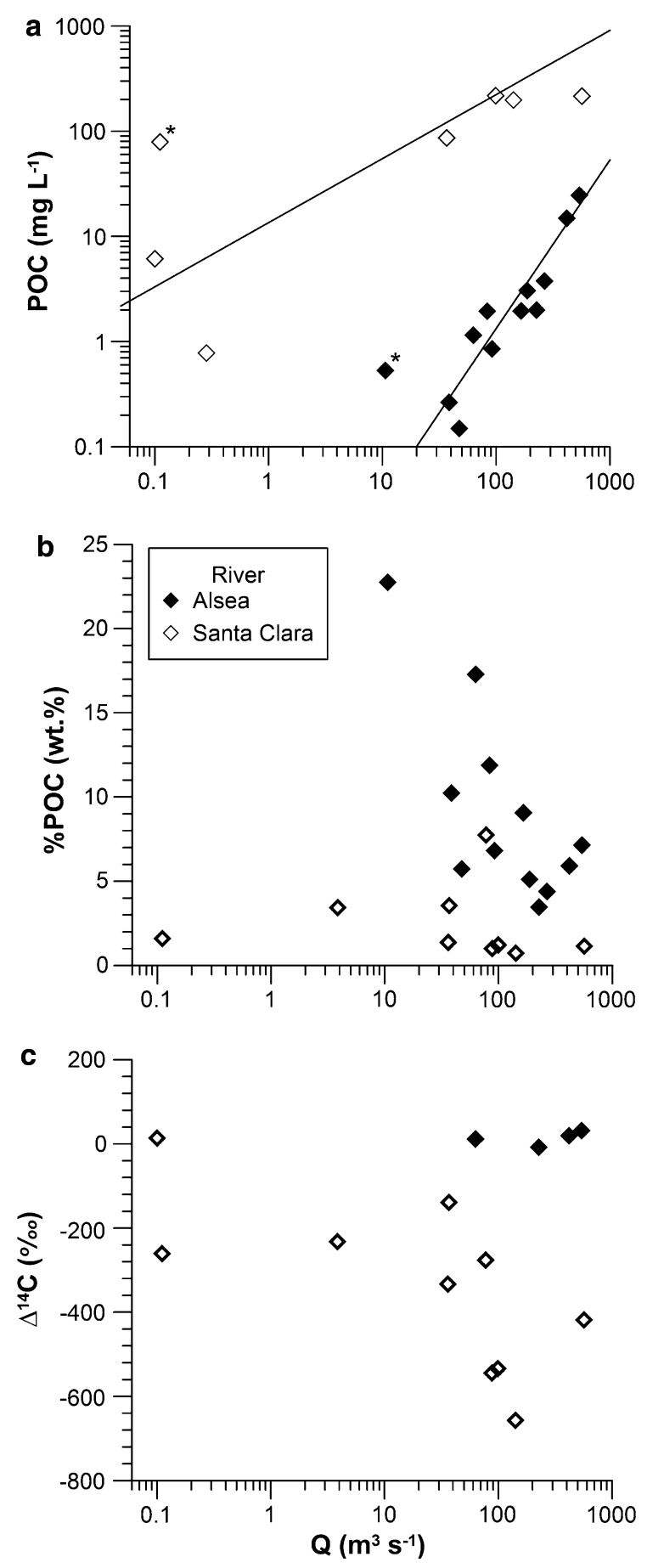

several biogeochemical and geomorphic factors, such as net primary productivity, soil formation rates, tectonic uplift rates and bedrock geology, appear to be critical factors in controlling POC export by this and other SMRS. 
Fig. 8 Biomarker ratios of a syringyl phenols/vanillyl phenols (SV:VP), b cutin acids/vanillyl phenols (CA:VP), and c amino acid-derived products/vanillyl phenols (AA:VP) for the fine (solid symbols) and coarse (open symbols) fractions as a function of discharge (Q). Included in these graphs are compositional ranges for different types of vegetation sources based on previous publications (e.g., Hedges and Mann 1979; Goñi and Hedges 1990a, 1992). The symbols for the vegetation sources include: $G$ gymnosperm woods, $A$ angiosperm woods, $g$ gymnosperm needles, $a$ angiosperm leaves and grasses

Composition and provenance of particulate organic matter

Discharge also plays an important role in the composition of POM carried by the Alsea River (Table 3, Fig. 7b). Using these compositional data to directly assess particle erosion/mobilization mechanisms such as surface sheet wash, gullying, and landslides is difficult because of the multiple processes that alter POM compositions. However, the geochemical signatures we measured provide information about the provenance and cycling of the POM that can be used to constrain particle sources in this (as well as other) SMRS. For example, suspended particles at low flows $\left(<90 \mathrm{~m}^{3} \mathrm{~s}^{-1}\right)$ are characterized by elevated $\% \mathrm{OC}$ and $\% \mathrm{ON}$ contents of $>10$ and $>1 \mathrm{wt} \%$, respectively, and at the very lowest flows by $\% \mathrm{OC}$ contents $>20 \mathrm{wt} \%$ (Table 3 ). As previously shown, under these low flow conditions, the POM is characterized by relatively low $\mathrm{C}: \mathrm{N}$ ratios and enriched $\delta^{13} \mathrm{C}$ and $\delta^{15} \mathrm{~N}$ signatures (Table 3). Furthermore, the sample collected during base flow conditions $\left(\mathrm{Q}=11 \mathrm{~m}^{3} \mathrm{~s}^{-1}\right) \quad$ displays elevated OC-normalized concentrations of non-vegetation biomarkers such as AA and markedly lower concentrations of vegetation biomarkers such as VP (Table 4). Overall, these compositions strongly suggest that at low flows the suspended load in the Alsea River is composed of organic detritus with a predominant non-vegetation source, consistent with particles being primarily derived from microalgae. Similar conclusions have been reached in other SMRS (e.g. Coynel et al. 2005) reflecting the distinct character of the suspended load at base flows.

As flows increase, the carbon content of the suspended load quickly decreases to values $<5 \mathrm{wt} \%$. Because the absolute OC concentrations ( $\mathrm{mg} \mathrm{l}^{-1}$ ) increase exponentially as a function of discharge, this trend is not due to the dilution of OM by mineral material as discharge increases. Instead, these data a
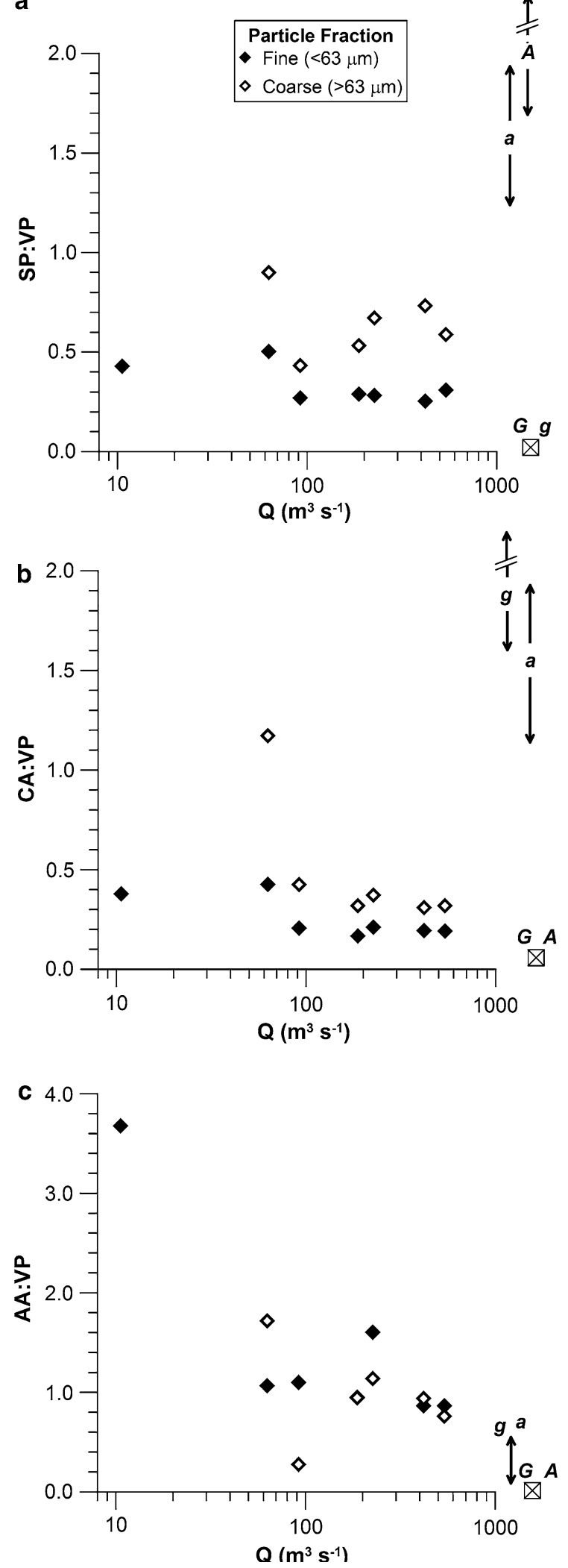
suggest that the character of the material changes dramatically from organic-rich particles at low flows to mineral-rich particles at high flows. Because these trends are observed in both fine and coarse particles (Table 3), we can infer that as discharge and suspended load increase, erosion and transport processes in the Alsea watershed entrain particles with increasingly higher mineral content. The data presented in the results section clearly show that under these conditions, the composition of POM exported by the Alsea River is characterized by relatively high $\mathrm{C}: \mathrm{N}$ ratios and depleted $\delta^{13} \mathrm{C}$ and $\delta^{15} \mathrm{~N}$ signatures (Table 3). Furthermore, the OC-normalized concentrations of ligninderived phenols increase significantly with increasing discharge. These trends point towards an increase in the contributions of vegetation-derived carbon to the POM exported by the Alsea River at high flows. One likely source of these mineral-rich, relatively OC-poor particles are soils within the basin, which are initially mobilized by shallow landslides that supply the majority of the particulate material to channel networks in this region of the OCR (Dietrich and Dunne 1978; Benda and Dunne 1997; Roering et al. 1999). As discussed in the previous section, because floods disproportionally dominate the particle export of the Alsea River, we can conclude that vegetation- and soilderived organic matter make up the bulk of the POM exported by this system.

The progressive decrease in the OC content of the suspended load as a function of increasing discharge has been observed in other SMRS (e.g., Coynel et al. 2005) although in some cases this trend has been incorrectly explained as a simple dilution by mineral material. A more accurate way to describe the mechanism responsible for this trend is that as $\mathrm{Q}$ increases, there is an enhanced entrainment of denser fractions of soil organic matter that are enriched in mineral material and have lower \%OC contents (e.g., Sollins et al. 2009). In the case of the Santa Clara River (Masiello and Druffel 2001), with a few exceptions, the \%OC contents of suspended sediment samples also generally decrease with Q (Fig. 7b). The most significant difference between the two systems; however, is the markedly lower \%OC contents of Santa Clara River particles $(0.7-4 \mathrm{wt} \%)$ relative to those of the Alsea River. Such contrast is most likely due to the significant entrainment of bedrock materials, with very low \%OC contents, by the Santa Clara systems at basically all discharges.
The marked differences in the radiocarbon composition of POM from the Alsea and Santa Clara Rivers (Fig. 7c) further illustrate the fundamental contrast in the character of their suspended particle loads. Whereas all POM (fine and coarse) transported by the Alsea River over a $50 \times$ range in discharge is basically modern in age $\left(\Delta^{14} \mathrm{C}_{\text {org }} \sim 0 \%\right)$, the POM in the Santa Clara River is generally much older $\left(-700 \%<\Delta^{14} \mathrm{C}_{\text {org }}<0 \%\right.$ ) and becomes increasingly depleted in ${ }^{14} \mathrm{C}$ with increasing $\mathrm{Q}$ (Fig. 7c). The contrasts in POM age between the Alsea and Santa Clara rivers are similar to those observed by Leithold et al. (2006) between low and high sediment-yield rivers in Oregon, northern California and New Zealand. Komada et al. (2004) concluded that the patterns in $\Delta^{14} \mathrm{C}_{\text {org }}$ of the suspended load in the Santa Clara River are due to the progressively greater entrainment and transport of petrogenic carbon derived from bedrock during periods of high flow. We infer that the high uplift rates, friable sedimentary rocks, sparse vegetation, low net primary production and thin soils of the Santa Clara basin explain the observed trend of elevated export of OM-poor sediment containing fossil $\left({ }^{14} \mathrm{C}\right.$-free $)$ organic carbon. Hence, erosion process in the basin mobilize sediment containing both biogenic and petrogenic sources of carbon, with the latter dominating the composition during high discharge periods. In contrast, in the Alsea River basin, lower uplift rates, lush vegetation, high net primary production and relatively thick soils lead to the mobilization of modern, biogenic OM derived from vegetation and surface soils. All our measurements indicate that under the flow conditions sampled, bedrock sources contribute little to the overall suspended load exported by this SRMS. Our findings are consistent with what is knows about the erosion mechanism in this region of the OCR. Several authors (e.g., Dietrich and Dunne 1978; Roering et al. 1999) have suggested uplift and erosion rates in the central OCR are at steady state. Because even at the highest discharges the Alsea River exports predominantly modern OM, we conclude that the incorporation rates of biogenic carbon into soils must be relatively high to maintain the supply of modern $\mathrm{POM}$ at erosion rates of $0.1-0.3 \mathrm{~mm}$ year $^{-1}$.

The specific sources of the biogenic materials dominating POM transport in the Alsea River system can be evaluated further by examining trends in biomarker compositions (Table 4, Fig. 8) through the 
use of biomarker-based ratios. For example, syringyl:vanillyl phenol ratios (SP:VP) provide information on the relative contributions of lignin from angiosperms (i.e., hardwood trees, which uniquely synthesize SP) versus gymnosperms (i.e., conifers that do no synthesize SP). Additional insight can be gained from cutin acid:vanillyl phenol ratios (CA:VP) because the former are enriched in non-woody tissues (e.g., leave and needles, roots), whereas VP are synthesized by both woody and non-woody angiosperm and gymnosperm vegetation sources (Goñi and Hedges 1990a, 1992; Filley et al. 2008). Lastly, we can expect contributions from non-vegetation sources (e.g., algae, fungi and bacteria), which contain elevated amounts of proteins and no lignin, to raise the ratios of amino acid-derived products to vanillyl phenols (AA:VP) in river POM.

Fine and coarse particles display biomarker ratios that provide novel information on the sources of biogenic POM within the Alsea watershed (Fig. 8). In order to provide a context for the magnitude of these ratios, we have also included in these graphs the compositional ranges of major vascular plant tissues, such as gymnosperm woods $(\mathrm{G})$, angiosperm woods (A), gymnosperm needles ( $\mathrm{g}$ ) and angiosperm leaves and grasses (a) (e.g., Hedges and Mann 1979; Goñi and Hedges 1990a, 1992, 1995). River particles display SP:VP ratios that range from 0.2 to 1.0 and plot between ranges of gymnosperm and angiosperm tissues (Fig. 8a). Furthermore, SP:VP ratios are consistently higher in coarse particles relative to fine particles and show no trend with Q. These results indicate both gymnosperm and angiosperm vegetation contribute to the POM exported by the river with little changes in their relative importance at increasing flows.

The consistently higher SP:VP ratio in coarse POM relative to fine POM suggests that the angiosperm contributions are greater for the larger particle size class. Because SP:VP ratios can be partially altered by lignin microbial decay due to the preferential loss of syringyl units (e.g., Hedges et al. 1988; Goñi et al. 1993), it is difficult to interpret these ratios beyond a semi-quantitative estimation of the relative importance of conifers versus hardwood contributions. On the other hand, fine and coarse particles showed no significant differences in several compositional parameters, including acid:aldehyde ratios of lignin phenols and 3,5-dihydroxybenzoic acid:vanillyl phenol ratios, that have been used to constrain the extent of lignin degradation (e.g., Hedges et al. 1988; Goñi et al. 1993; Prahl et al. 1994). Hence, from the SP:VP ratios we can infer that the provenance of the lignin transported by the river is likely to be from areas with mixed vegetation, rather than upland regions that are covered predominantly by conifer forests.

Roering et al. (2003) found that the vegetation surrounding the headscarps of shallow landslides, which are important source of sediment to channel network systems in this region of the OCR (Dietrich and Dunne 1978; Roering et al. 1999) was primarily hardwood species such as red alder. Hence, the higher than expected contributions from angiosperm vegetation elucidated from the SP:VP ratios may indicate suspended POM in the river originates from litter and surface soils from these areas. Riparian zones adjacent to streams are also dominated by the same angiosperm species (e.g., Harrington et al. 1994) and the elevated SP:VP ratios may also indicate inputs from these regions. Because nearly all POM mobilized by the Alsea is modern in age, the residence time of organic matter in these likely sediment sources cannot be very long ( $<60$ year) and suggest a rapid transfer of vegetation- and soil-derived carbon to the stream network. Previous studies have tried to constrain the importance of hardwood species, specifically those from nitrogen-fixing red alder, in forested ecosystems from the OCR (e.g., Scott et al. 2008) by using $\delta^{13} \mathrm{C}$ and $\delta^{15} \mathrm{~N}$ compositions. However, this work showed that it was often impossible to differentiate red alder-derived organic matter from Douglas fir-derived organic matter in riparian forest within the OCR. In that respect, our results show the potential of these biomarker-based measurements to discriminate between conifer and angiosperm OM sources.

River POM displays CA:VP ratios that range from 0.2 to 1.0 , with consistently higher values for the coarse fraction relative to the fine fraction (Fig. 8b). The CA:VP values exhibited by the suspended particles fall between the ranges for non-woody tissues (e.g., needles, leaves, grasses) and woody tissues (both gymnosperm and angiosperm) (Goñi and Hedges 1990a), suggesting both of these sources contribute to the POM transported by the river. The differential degradation rates of cutin and lignin under natural conditions (Goñi and Hedges 1990b) 
make it difficult to interpret these results beyond semi-quantitative inferences. As was the case with SP:VP ratios, there is not a clear trend between $\mathrm{CA}$ :VP ratios and discharge. However, it is important to note that the highest CA:VP values in both coarse and fine particles were measured in samples collected during November. These differences may reflect contributions from freshly deposited (i.e. less degraded) needle and leaf litter in the early fall. Much more frequent sampling intensity is needed to assess whether or not there are seasonal differences in the composition of the POM (e.g., Wheatcroft et al. 2010), but our preliminary observations suggest it may be possible to detect them using this biomarker approach. Regarding the specific sources of the cutin acids, as mentioned previously, the elevated dihydroxyhexadecanoic acid: $\omega$-hydroxyoctadecenoic acid ratios $(>60)$ in all Alsea River samples are consistent with low contributions from belowground vascular plant tissues such as roots (e.g., Filley et al. 2008). This result argues against a significant entrainment of OM from deeper soil horizons and instead supports the hypothesis that most of the organic materials transported by the Alsea River originate from surface litter and soils with relatively low residence times (i.e. modern $\Delta^{14} \mathrm{C}$ signatures) in the watershed.

Figure $8 \mathrm{c}$ shows the AA:VP ratios in fine and coarse POM range from 0.3 to almost 4.0. Unlike the vegetation-derived biomarker ratios discussed above, no consistent differences in AA:VP are apparent between the fine and coarse fractions. Furthermore, AA:VP ratios are significantly higher during periods of low flow, with values that exceed those expected from vegetation sources such as leaves, needles, and woody debris. The elevated AA:VP ratios $(>2)$ measured at low flows are consistent with our interpretation that under these conditions most particles carried by the Alsea River originate from algal or other non-vegetation sources devoid of lignin. Microbial-mediated humification reactions in soils have been shown to add protein-rich OM to the decomposing plant detritus (e.g., Sorensen 1981). Hence, it is likely that the AA:VP values $\sim 1$ that are observed at moderate to high flows reflect the input of POM modified by humification processes. Overall, the trends in AA:VP ratios are consistent with previously discussed variations in \%OC contents, $\mathrm{C}: \mathrm{N}$ ratios and stable carbon compositions and underscore the stark difference in the quality of the
POM transported by the Alsea River during low versus high flows.

Relevance of POM fluxes to watershed carbon balances

Our discussion up to this point has focused on the concentration and compositional differences of the particulate load of the Alsea River as a function of discharge. In this section we evaluate how these findings are related to the overall carbon balance of the watershed. For this purpose, it is useful to consider the magnitude of the POC exported by the Alsea River at Tidewater (i.e. $3.3 \times 10^{6} \mathrm{~kg} \mathrm{OC}$ year $^{-1}$; see previous discussion) relative to the net primary production $\left(\sim 0.9 \times 10^{6} \mathrm{~kg} \mathrm{OC} \mathrm{km}^{-2}\right.$ year $\left.^{-1}\right)$ and soil carbon storage $\left(32 \times 10^{6} \mathrm{~kg} \mathrm{~km}^{-2}\right)$ in the basin. The estimated POC flux at Tidewater corresponds to a yield of $\sim 3.8 \times 10^{3} \mathrm{~kg}$ of POC $\mathrm{km}^{-2}$ year $^{-1}$. If this estimate is representative of most years, it indicates that the annual export of POC by the Alsea River only represents a miniscule $\left(10^{-4}\right)$ fraction of the soil carbon stored in the basin. Assuming the POC yield determined at Tidewater applies to the entire basin, the total POC exported to the ocean is $\sim 4.6 \times 10^{6} \mathrm{~kg} \mathrm{year}^{-1}$. If this flux is representative of average conditions, it means that the Alsea River exports $\sim 0.4 \%$ of the annual net primary production of the basin as POC.

The Santa Clara River data of Masiello and Druffel (2001) illustrated in Fig. 7a were for the 1997-1998 period, which was an El Nino year and an unusual wet period in southern California. Assuming the $Q$ versus POC-concentration relationship determined by these authors (Fig. 7a) holds for years of average discharge, such as 2001, the average POC export of the Santa Clara River is $\sim 86 \times 10^{6} \mathrm{~kg}$ POC, representing an annual yield of $21 \times 10^{3} \mathrm{~kg}$ POC km ${ }^{-2}$ year $^{-1}$. However, because a significant fraction of the POM in the Santa Clara is petrogenic, whereas the Alsea exports primarily biogenic POM, this yield comparison does not account for differences in the source of POC. To address this issue, we used the $\Delta^{14} \mathrm{C}-\mathrm{Q}$ relationship measured by Masiello and Druffel (2001; Fig. 7c) to calculate the export of modern POC $\left(\mathrm{POC}_{\mathrm{mod}}\right)$. In 2001, we estimate the Santa Clara exported $\sim 41 \times 10^{6} \mathrm{~kg} \mathrm{POC}_{\text {mod }}$ year $^{-1}$, which represents a yield of $9.7 \times 10^{3} \mathrm{~kg} \mathrm{POC}_{\text {mod }} \mathrm{km}^{-2}$ year $^{-1}$. Based on the estimates of NPP for Chaparral 
ecosystems in southern California $\left(\sim 0.2 \times 10^{6} \mathrm{~kg}\right.$ OC km ${ }^{-2}$ year $^{-1}$; Gray and Schlesinger 1981), POC $_{\text {mod }}$ export by the Santa Clara in 2001 accounted for $\sim 4 \%$ of the NPP.

Clearly, because of the limited observations they are based on, these calculations only represent a rough characterization of POM dynamics in these two watersheds. Given the large uncertainties, it is informative to note that despite its significantly lower discharge, lower productivity and biomass, the Santa Clara SMRS appears to export more biogenic carbon per $\mathrm{km}^{2}$ than the Alsea system, which is characterized by higher water discharge, greater productivity and biomass. Furthermore, it appears the Santa Clara River exports a significantly higher fraction of the net watershed primary production than the Alsea SMRS. These preliminary conclusions appear to lend support to the idea that tectonic factors, rather than hydroclimatic and/or biologic factors, are responsible for the contrasts between these two systems. Given our understanding of these two systems, it seems the higher uplift rates and elevated erosion in the Santa Clara system relative to the Alsea system exert a dominant forcing in POM export that overwhelms those other factors. Future research should focus on other SMRS to test whether these inferences apply to other watersheds with contrasting characteristics. The insights resulting from such additional work will be critical for our ability to extrapolate the measurements from specific rivers and improve our estimates of global materials fluxes by SMRS.

\section{Summary}

As in previously studied SMRS, the export of particulate materials by the Alsea River primarily takes place during floods, which in this system coincide with the passage of winter storms. The compositional characteristics determined in this study indicate the majority of the POM mobilized by Alsea River ultimately originates from vegetation sources that have been altered during their cycling in surface soils. Only at very low discharges, when the input of mineral-rich particles is very low, do non-vegetation sources such as algae appear important. Comparison of our results with those from the well-studied Santa Clara River indicates there are major differences in POM concentrations and composition between these two systems. The high sediment and petrogenic POC yields in the Santa Clara River reflect the higher rates of bedrock erosion associated with rapid tectonic uplift and thin soil coverage in this system relative to those in the Alsea River. In the latter, low tectonic uplift coupled with thick soil mantle and high NPP rates, basically result in the export of modern biogenic POM at all discharges.

Our observations add to the growing body of literature examining the relationships between discharge and suspended POM concentrations and compositions in rivers worldwide. We conclude that variations in the combination of geomorphic and biologic factors likely exert fundamental controls on the nature and magnitude of the POM exported by SMRS. However, as our preliminary calculations indicate, the actual amounts of fossil and modern POC exported on an annual basis by these and other SMRS systems depend highly on the total discharge for each particular year. Making such comparisons over longer periods of time is beyond the scope of this paper, but we believe this approach is likely to be fruitful and can be used to contrast different river basins while accounting for the key temporal differences in discharge. Further insights into the role that SMRS play in global biogeochemical cycles require focused studies of the processes responsible for the mobilization and transport of particulate materials and the formulation of conceptual models that facilitate upscaling (e.g., Wheatcroft et al. 2010).

Acknowledgments We thank Y. Alleau, E. Mulroney, J. Bechler, R. Hastings R. Holser, C. Burck and C. Sande for their help in collecting and analyzing the samples for this study. The manuscript benefited from comments by Robert Hilton and one anonymous reviewer. Funding from this work was provided by grant EAR 0628487 from the National Science Foundation awarded to Goñi and Wheatcroft.

Open Access This article is distributed under the terms of the Creative Commons Attribution Noncommercial License which permits any noncommercial use, distribution, and reproduction in any medium, provided the original author(s) and source are credited.

\section{References}

Aller RC, Blair NE (2004) Early diagenetic remineralization of sedimentary organic $\mathrm{C}$ in the Gulf of Papua deltaic complex (Papua New Guinea): net loss of terrestrial C nd diagenetic fractionation of $\mathrm{C}$ isotopes. Geochim Cosmochim Acta 68:1815-1825 
Almond P, Roering J, Hales TC (2007) Using soil residence time to delineate spatial and temporal patterns of transient landscape response. J Geophys Res Earth Surf 112. doi: 10.1029/2006JF000568

Benda L, Dunne T (1997) Stochastic forcing of sediment routing and storage in channel networks. Water Resour Res 33:2865-2880

Bianchi TS, Galler JJ, Allison MA (2007) Hydrodynamic sorting and transport of terrestrially derived organic carbon in sediments of the Mississippi and Atchafalaya Rivers. Estuar Coast Shelf Sci 73:211-222

Blair NE, Leithold EL, Ford ST, Peeler KA, Holmes JC, Perkey DW (2003) The persistence of memory: the fate of ancient sedimentary organic carbon in a modern sedimentary system. Geochim Cosmochim Acta 67: 63-73

Blair NE, Leithold EL, Aller RC (2004) From bedrock to burial: the evolution of particulate organic carbon across coupled watershed-continental margin systems. Mar Chem 92:141-156

Cohn TA (1995) Recent advances in statistical-methods for the estimation of sediment and nutrient transport in rivers. Rev Geophys 33:1117-1123

Cohn TA, Caulder DL, Gilroy EJ, Zynjuk LD, Summers RM (1992) The validity of a simple statistical model for estimating fluvial constituent loads: an empirical study involving nutrient loads entering Chesapeake Bay. Water Resour Res 28:2353-2363

Compton JE, Church MR, Larned ST, Hogsett WE (2003) Nitrogen export from forested watersheds in the Oregon Coast Range: the role of N-2-fixing red alder. Ecosystems 6:773-785

Coynel A, Etcheber H, Abril G, Maneux E, Dumas J, Hurtrez J-E (2005) Contribution of small mountainous rivers to particulate organic carbon input in the Bay of Biscay. Biogeochemistry 74:151-171

Crow SE, Filley TR, McCormick M, Szlavecz K, Stott DE, Bamblin D, Conyers G (2009a) Earthworms, stand age, and species composition interact to influence particulate organic matter chemistry during forest succession. Biogeochemistry 92:61-82

Crow SE, Lajtha K, Filley TR, Swanwon CW, Bowden RD, Caldwell BA (2009b) Sources of plant-derived carbon and stability of organic matter in soil: implications for global change. Glob Chang Biol 15:2003-2019

Dalzell BJ, Filley TR, Harbor JM (2007) The role of hydrology in annual organic carbon loads and terrestrial organic matter export from a midwestern agricultural watershed. Geochim Cosmochim Acta 71:1448-1462

Dietrich WE, Dunne T (1978) Sediment budget for a small catchment in mountainous terrain. Zeitschrift fur Geomorphologie, Supplement 29:191-206

Drenzek NJ, Hughen KA, Montlucon DB, Southon JR, dos Santos GM, Druffel ERM, Giosan L, Eglinton TI (2009) A new look at old carbon in active margin sediments. Geology 37:239-242

Filley TR, Boutton TW, Liao JD, Jastrow JD, Gamblin DE (2008) Chemical changes to nonaggregated particulate soil organic matter following grassland-to-woodland transition in a subtropical savanna. J Geophys Res 113:G03009. doi: 10.1029/JG000564
Gabet EJ, Dunne T (2003) A stochastic sediment delivery model for a steep Mediterranean landscape. Water Resour Res 39:1237. doi:10.1029/2003WR002341

Galy V, France-Lanord C, Lartiges B (2008) Loading and fate of particulate organic carbon from the Himalaya to the Ganga-Brahmaputra delta. Geochim Cosmochim Acta 72:1767-1787

Gomez B, Trustrum NA, Hicks DM, Rogers KM, Page MJ, Tate KR (2003) Production, storage, and output of particulate organic carbon: Waipaoa River basin, New Zealand. Water Resour Res 39. doi:10.1029/2002WR001619

Goñi MA, Hedges JI (1990a) Potential applications of cutinderived Cuo reaction products for discriminating vascular plant tissues in natural environments. Geochim Cosmochim Acta 54:3073-3081

Goñi MA, Hedges JI (1990b) The diagenetic behavior of cutin acids in buried conifer needles and sediments from a coastal marine environment. Geochim Cosmochim Acta 54:3083-3093

Goñi MA, Hedges JH (1992) Lignin dimers: structures, distribution and potential geochemical applications. Geochim Cosmochim Acta 56:4025-4043

Goñi MA, Hedges JI (1995) Sources and reactivities of marinederived organic matter in coastal sediments as determined by alkaline $\mathrm{CuO}$ oxidation. Geochim Cosmochim Acta 59:2965-2981

Goñi M, Montgomery S (2000) Alkaline CuO oxidation with a microwave digestion system: lignin analyses of geochemical samples. Anal Chem 72:3116-3121

Goñi MA, Nelson B, Blanchette RA, Hedges JI (1993) Fungal degradation of wood lignins: geochemical perspectives from $\mathrm{CuO}$-derived phenolic dimers and monomers. Geochim Cosmochim Acta 57:3985-4002

Goñi M, Teixeira M, Perkey D (2003) Sources and distribution of organic matter in a river-dominated estuary (Winyah Bay, SC, USA). Estuar Coast Shelf Sci 57:1023-1048

Goñi MA, Cathey MW, Kim YH, Voulgaris G (2005a) Fluxes and sources of suspended organic matter in an estuarine turbidity maximum region during low discharge conditions. Estuar Coast Shelf Sci 63:683-700

Goñi MA, Yunker MB, Macdonald RW, Eglinton TI (2005b) The supply and preservation of ancient and modern components of organic carbon in the Canadian Beaufort Shelf of the Arctic Ocean. Mar Chem 93:53-73

Goñi MA, Monacci N, Gisewhite R, Crockett J, Nittrouer C, Ogston A, Alin SR, Aalto R (2008) Terrigenous organic matter in sediments from the Fly River delta-clinoform system (Papua New Guinea). J Geophys Res 113. doi: 10.1029/2006JF000653

Goñi MA, Aceves H, Benitez-Nelson B, Tappa E, Thunell R, Black DE, Muller-Karger F, Astor Y, Varela R (2009) Oceanographic and climatologic controls on the compositions and fluxes of biogenic materials in the water column and sediments of the Cariaco Basin over the Late Holocene. Deep Sea Res Part I 56:614-640

Gough MA, Fauzi R, Mantoura C, Preston M (1993) Terrestrial plant biopolymers in marine sediments. Geochim Cosmochim Acta 57:945-964

Gray JT, Schlesinger WH (1981) Biomass, production, and litterfall in the coastal sage scrub of Southern-California. Am J Bot 68:24-33 
Harrington CA, Zasada JC, Allen EA (1994) Biology of red alder (Alnus rubra Bong.). In: Hibbs DE, DeBell DS, Tarrant RF (eds) The biology and management of red alder. Oregon State University Press, Corvallis, pp 3-22

Hartnett HE, Keil RG, Hedges JI, Devol AH (1998) Influence of oxygen exposure time on organic carbon preservation in continental margin sediments. Nature 391:572-574

Hedges JI, Mann DC (1979) The characterization of plant tissues by their lignin oxidation products. Geochim Cosmochim Acta 43:1803-1807

Hedges JI, Stern JH (1984) Carbon and nitrogen determinations of carbonate-containing solids. Limnol Oceanogr 29: $657-663$

Hedges JI, Blanchette RA, Weliky K, Devol AH (1988) Effects of fungal degradation on the $\mathrm{CuO}$ oxidation products of lignin: a controlled laboratory study. Geochim Cosmochim Acta 52:2717-2726

Hilton RG, Galy A, Hovius N (2008a) Riverine particulate organic carbon from an active mountain belt: importance of landslides. Global Biogeochemical Cycles 22:GB1017. doi:10.1029/2006GB002905

Hilton RG, Galy A, Hovius N, Chen MC, Horng MJ, Chen HY (2008b) Tropical-cyclone-driven erosion of the terrestrial biosphere from mountains. Nat Geosci 1:759-762

Hoover D, Mackenzie F (2009) Fluvial fluxes of water, suspended particulate matter, and nutrients and potential impacts on tropical coastal water biogeochemistry: Oahu, Hawaii. Aquat Geochem 15:547-570

Houel S, Louchouarn P, Lucotte M, Canuel R, Ghaleb B (2006) Translocation of soil organic matter following reservoir impoundment in boreal systems: implications for in situ productivity. Limnol Oceanogr 51:1497-1513

Howden NJK, Bowes MJ, Clark ADJ, Humphries N, Neal C (2009) Water quality, nutrients and the European union's Water Framework Directive in a lowland agricultural region: Suffolk, south-east England. Sci Total Environ 407:2966-2979

Kao S-J, Liu KK (1996) Particulate organic carbon export from a subtropical mountainous liver (Lanyang Hsi) in Taiwan. Limnol Oceanogr 41:1749-1757

Kastner T, Goñi MA (2003) Constancy in the vegetation of the Amazon Basin during the late Pleistocene: evidence from the organic matter composition of Amazon deep sea fan sediments. Geology 31:291-294

Kelsey HM, Ticknor RL, Bockheim JG, Mitchell CE (1996) Quaternary upper plate deformation in coastal Oregon. Geol Soc Am Bull 108:843-860

Komada T, Druffel ERM, Trumbore SE (2004) Oceanic export of relict carbon by small mountainous rivers. Geophys Res Lett 31. doi:10.1029/2004GL019512

Komada T, Druffel ERM, Hwang J (2005) Sedimentary rocks as sources of ancient organic carbon to the ocean: an investigation through Delta C-14 and delta C-13 signatures of organic compound classes. Global Biogeochemical Cycles 19. doi:10.1029/2004GB002347

Lal R (2003) Soil erosion and the global carbon budget. Environ Int 29:437-450

Leithold EL, Blair NE, Perkey DW (2006) Geomorphologic controls on the age of particulate organic carbon from small mountainous and upland rivers. Global Biogeochem Cycles 20:GB3022. doi:3010.1029/2005GB002677
Lovell JPB (1969) Tyee formation: undeformed turbidites and their lateral equivalents: mineralogy and paleogeography. Geol Soc Am Bull 30:443-446

Lyons WB, Nezat CA, Carey AE, Hicks DM (2002) Organic carbon fluxes to the ocean from high-standing islands. Geology 30:443-446

Masiello C, Druffel E (2001) Carbon isotope geochemistry of the Santa Clara River. Global Biogeochem Cycles 15: 407-416

Mayer LM (1994) Surface area control of organic carbon accumulation in continental shelf sediments. Geochim Cosmochim Acta 58:1-14

Milliman JD, Syvitski JPM (1992) Geomorphic/tectonic control of sediment discharge to the ocean: the importance of small mountainous rivers. J Geol 100:525-544

Montgomery DR (2001) Slope distributions, threshold hillslopes, and steady-state topography. Am J Sci 301:432454

Nakamura F, Swanson FJ, Wondzell SM (2000) Disturbance regimes of stream and riparian systems-a disturbancecascade perspective. Hydrol Process 14:2849-2860

Otto A, Simpson MJ (2006) Evaluation of $\mathrm{CuO}$ oxidation parameters for determining the source and stage of lignin degradation in soil. Biogeochemistry 80:121-142

Prahl FG, Ertel JR, Goñi MA, Sparrow MA, Eversmeyer B (1994) Terrestrial organic carbon contributions to sediments on the Washington margin. Geochim Cosmochim Acta 58:3035-3048

Raymond PA, Bauer JE, Caraco NF, Cole JJ, Longworth B, Petsch ST (2004) Controls on the variability of organic matter and dissolved inorganic carbon ages in northeast US rivers. Mar Chem 92:353-366

Roering JJ, Kirchner JW, Dietrich WE (1999) Evidence for nonlinear, diffusive sediment transport on hillslopes and implications for landscape morphology. Water Resour Res 35:853-870

Roering JJ, Schmidt KM, Stock JD, Dietrich WE, Montgomery DR (2003) Shallow landsliding, root reinforcement, and the spatial distribution of trees in the Oregon Coast Range. Can Geotech J 40:237-253

Roering JJ, Kirchner JW, Dietrich WE (2005) Characterizing structural and lithologic controls on deep-seated landsliding: implications for topographic relief and landscape evolution in the Oregon Coast Range, USA. Geol Soc Am Bull 117:654-668

Scott EE, Perakis SS, Hibbs DE (2008) d15N Patterns of Douglas-fir and red alder riparian forests in the Oregon Coast Range. For Sci 54:140-147

Smith SV, Renwick WH, Buddemeier RW, Crossland CJ (2001) Budgets of soil erosion and deposition for sediments and sedimentary organic carbon across the conterminous United States. Global Biogeochem Cycles 15:697-707

Soil Survey Staff NRCS (2009) Web Soil Survey, edited. United States Department of Agriculture

Sollins P, Swanston C, Kleber M, Filley T, Kramer M, Crow S, Caldwell BA, Lajtha K, Bowden R (2006) Organic C and $\mathrm{N}$ stabilization in a forest soil: evidence from sequential density fractionation. Soil Biol Biochem 38:3313-3324

Sollins P, Kramer MG, Swanston C, Lajtha K, Filley T, Aufdenkampe AK, Wagai R, Bowden RD (2009) Sequential 
density fractionation across soils of contrasting mineralogy: evidence for both microbial- and mineral-controlled soil organic matter stabilization. Biogeochemistry 96:209-231

Sorensen LH (1981) Carbon-nitrogen relationships during the humification of cellulose in soils containing different amounts of clay. Soil Biol Biochem 13:313-321

StillwaterSciences (2007) Santa Clara River Parkway floodplain restoration feasibility study: assessment of geomorphic processes for the Santa Clara River Watershed, Ventura and Los Angeles counties, California. Prepared by Stillwater Sciences for the California State Coastal Conservancy, Berkeley

Stuiver M, Polach HA (1977) Discussion: reporting of ${ }^{14} \mathrm{C}$ data. Radiocarbon 19:355-363

Syvitski JP, Morehead MD, Bahr DB, Mulder T (2000) Estimating fluvial sediment transport: the rating parameters. Water Resour Res 36:2747-2760

Tesi T, Langone L, Goñi MA, Turchetto M, Miserocchi S, Boldrin A (2008) Source and composition of organic matter in the Bari canyon (Italy): dense water cascading versus particulate export from the upper ocean. Deep Sea Res Part I 55:813-831

Van Tuyl S, Law BE, Turner DP, Gitelman AI (2005) Variability in net primary production and carbon storage in biomass across Oregon forests - an assessment integrating data from forest inventories, intensive sites, and remote sensing. For Ecol Manage 209:273-291
Vogel JJ, Southen JR, Nelson DE (1987) Catalyst and binder effects in the use of filamentous graphite for AMS. Nucl Instrum Methods Phys Res B29:50-56

Wakeham SG, Canuel EA, Lerberg EJ, Mason P, Sampere TP, Bianchi TS (2009) Partitioning of organic matter in continental margin sediments among density fractions. Mar Chem 115:211-225

Warrick JA (2002) Short-term (1997-2000) and long-term (1928-2000) observations of river water and sediment discharge to the Santa Barbara Channel, California. Ph.D. Dissertation, Santa Barbara, p 337

Warrick JA, Mertes LAK (2009) Sediment yield from the tectonically active semiarid Western Transverse Ranges of California. Geol Soc Am Bull 121:1054-1070

Warrick JA, Washburn L, Brzezinski MA, Siegel DA (2005) Nutrient contributions to the Santa Barbara Channel, California, from the ephemeral Santa Clara River. Estuar Coast Shelf Sci 62:559-574

Wheatcroft RA, Sommerfield CK (2005) Rivers sediment flux and shelf sediment accumulation rates on the Pacific Northwest margin. Cont Shelf Res 25:311-332

Wheatcroft RA, Goñi MA, Hatten JA, Pasternack GB, Warrick JA (2010) The role of effective discharge in the ocean delivery of particulate organic matter by small, mountainous river systems. Limnol Oceanogr 55:161-171 